\title{
ВИМІРЮВАННЯ
}

ЯКОСТІ ЖИТТЯ

В УКРAїHI

\section{A НАЛ।ТИЧНА ДОПОВ।Д}




\section{ВИМІРЮВАННЯ ЯКОСТІ ЖИТТЯ В УКPAÏHI}

Київ - 2013 
Вимірювання якості життя в Україні, Аналітична доповідь, Лібанова Е.М., Гладун О.М., Лісогор Л.С. та ін. - K.: 2013

Доповідь підготовлено авторським колективом, до складу якого увійшли: Е.М. Лібанова, академік НАН України, д.е.н., проф.; О.М. Гладун, д.е.н.; Л.С. Лісогор, д.е.н.; Л.Г. Ткаченко, к.е.н.; Н.В. Ковтун, д.е.н., проф.; І.С. Марченко, к.е.н.; Андрій Іванов, міжнародний експерт; Михай Пелях, міжнародний експерт. Загальну координацію підготовки доповіді здійснено ПРООН в Україні.

Автори монографії висловлюють вдячність за продуктивну співпрацю та наукову підтримку науковим співробітникам відділів Інституту демографії та соціальних досліджень імені М.В. Птухи НАН України, науковцям Інституту соціології НАН України (Ю.І. Саєнко, А.С.Н., проф., Т.І. Петрушиній, д.с.н.), Київського національного університету імені Тараса Шевченка, Державній службі статистики України, Програмі Розвитку ООН. При підготовці монографії були використані дані науководослідної роботи «Розроблення системи індикаторів оцінки якості життя населення України для здійснення комплексного моніторингу, у тому числі порівняння з іншими країнами» Інституту демографії та соціальних досліджень імені М.В. Птухи НАН України.

Публікація може стати у нагоді урядовцям, працівникам міністерств та відомств, керівникам та фахівцям місцевих органів виконавчої влади, науковцям, діячам громадських організацій та спеціалістам з питань соціально-економічного й людського розвитку України. Результати досліджень можна використовувати у процесі розроблення стратегії управління якістю життя. Це надасть можливість підвищити ефективність та результативність державної політики у сферах охорони здоров'я, освіти, зайнятості, безпеки.

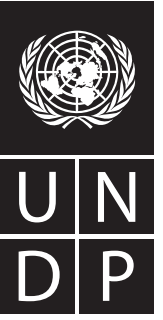

Empowered lives. Resilient nations.

\begin{abstract}
Цю доповідь підготовлено за сприяння Програми Розвитку ООН в Україні в рамках проекту «Прискорення прогресу на шляху досягнення Цілей Розвитку Тисячоліття в Україні».

Думки, висновки чи рекомендації належать авторам та упорядникам цього видання і не обов'язково відображають погляди ООН.

Програма розвитку ООН є глобальною мережею ООН в галузі розвитку, організацією, яка виступає за позитивні зміни та забезпечує країнам доступ до джерел знань, досвіду та ресурсів шляхом надання допомоги людям в усьому світі у розбудові кращого життя. Ми співпрацюємо з 177 країнами світу, допомагаючи їм знаходити власні шляхи розв'язання глобальних та національних проблем у галузі розвитку. Для змічнення власного потенціалу національні партнери мають змогу використовувати досвід і знання співробітників ПРООН та широкого кола наших партнерів. В Україні наша діяльність у галузі розвитку здійснюється за трьома основними напрямами: демократичне врядування та місцевий розвиток; подолання бідності, досягнення процвітання та українських Цілей Розвитку Тисячоліття; енергетика та навколишнє природне середовище. За кожним із напрямів ми забезпечуємо баланс між упровадженням заходів щодо розроблення політико-правових документів, аналітично-дорадчою діяльністю, заходами з поліпшення спроможності наших національних партнерів та окремими пілотними проектами. ПРООН впроваджує свою діяльність в Україні з 1993 року.
\end{abstract}

При використанні матеріалів посилання на джерело обов'язкове.

(c) Інститут демографії та соціальних досліджень імені М.В. Птухи НАН України, Програма Розвитку ООН, Міністерство економічного розвитку і торгівлі України, 2013 


\section{MICT}

ВСТУП............................................................

1. ТЕОРЕТИЧНІ ЗАСАДИ ВИМІРЮВАННЯ ЯКОСТІ ЖИТТЯ . ................7

2. ВИМІРЮВАННЯ ЯКОСТІ ЖИТТЯ: ІСНУЮЧІ ПІДХОДИ .................9

2.1. Міжнародний досвід вимірювання якості життя: можливості міжкраїнових порівнянь ....................

2.2. Підходи до вимірювання якості життя населення в окремих країнах

2.3. Досвід вимірювання окремих компонентів якості життя населення в Україні

\section{3. КОНЦЕПТУАЛЬНІ ПІДХОДИ ДО ВИМІРЮВАННЯ}

ЯКОСТІ ЖИТТЯ В УКРАЇНІ ....................................21

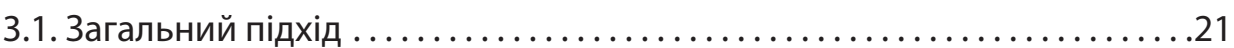

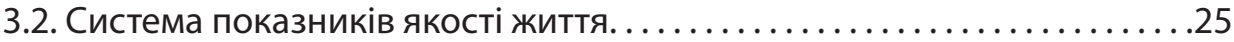

3.3. Розрахунок узагальнюючих показників ...................... 32

СПИСОК ВИКОРИСТАНИХ ДЖЕРЕЛ..............................34

\section{ДОДАТКИ}

Додаток А. Показники оцінювання якості життя за методологією the Economist Intelligence Unit

Додаток Б. Показники оцінювання якості життя за методологією Євростату (European Statistical System Committee) ...........37

Додаток В. Показники оцінювання якості життя за методологією журнала International Living........................43

Додаток Г. Показники оцінювання якості життя за методологією $\in C$ (European Foundation for the Improvement of Living and Working Conditions)

Додаток Д. Показники оцінювання якості життя за методологією Організації економічного співробітництва та розвитку (Better Life Index) 


\section{СПИСОК СКОРОЧЕНЬ}

ВВП Валовий внутрішній продукт

ВІЛ Вірус імунодефіциту людини

ВНП Валовий національний продукт

ДТП Дорожньо-транспортна пригода

Євростат Європейський комітет статистичних систем

$\in С$ Європейський Союз

НАН Національна академія наук

OECP Організація економічного розвитку та співробітництва

$\mathrm{OOH}$ Організація Об'єднаних Націй

ПРООН Програма Розвитку Організації Об'єднаних Націй

ПКС Паритети купівельної спроможності

РАН Російська академія наук

СНІД Синдром набутого імунодефіциту

США Сполучені Штати Америки

ЦРТ Ц Цілі Розвитку Тисячоліття 


\section{ВСТУП}

Цілі Розвитку Тисячоліття стали однією з найбільш успішних інновацій людства. ЦРТ $є$ одночасно і орієнтиром, і системою пріоритетів для реалізації стратегії реформ в Україні, оскільки вони визначають найгостріші проблеми, що стоять перед суспільством. Моніторинг прогресу досягнення ЦРТ, встановлених для України, відбувається за допомогою встановленого набору показників за завданнями ЦРТ. Обговорення стану досягнення ЦРТ стимулювало національний дискурс щодо становлення системи національного моніторингу суспільного розвитку України та шляхів його інституціалізації. Одним зі стратегічно важливих напрямів модернізації українського суспільства $\epsilon$ підвищення якості життя населення. Саме тому визначення ключових критеріїв якості життя та створення системи відповідних показників набуває пріоритетного значення. Нагальними завданнями $є$ побудова системи оцінювання якості життя населення, розроблення методичних підходів до вимірювання суспільного прогресу, детальне вивчення взаємного впливу усіх вимірів якості життя, усіх складових; визначення основних закономірностей проявів та зрушень у динаміці якості життя тощо.

Якість життя виступає складним, багатокомпонентним явищем, що залежить як від об'єктивних факторів (насамперед, можливості задоволення людських потреб та інтересів у даних соціально-економічних умовах), так і від різноманітних суб'єктивних факторів (соціально-психологічних, соціокультурних та інших).

Підвищення якості життя виступає критерієм і необхідною умовою людського розвитку. Концепція людського розвитку наголошує на пріоритетності ролі людини, визначаючи, що людина - мета економічного зростання, а не його ресурс. Концепцію людського розвитку було уведено в науковий обіг та у практику державного управління у 1990 році. Доповідь про людський розвиток Програми Розвитку ООН визначила центральну тезу однією фразою: «Реальне багатство народів - люди». Метою людського розвитку $є$ створення середовища, яке надає людям можливість прожити довге, здорове і творче життя. Концепція людського розвитку, сформульована більш ніж два десятиріччя тому, розвинулася з плином часу. У Доповіді про людський розвиток «Реальне багатство народів: шляхи людського розвитку» 2010 року представлено оновлене визначення людського розвитку: «Розширення можливостей і свобод людей, створення таких умов, які 6 дозволили людям прожити довге, здорове і продуктивне життя та досягти інших цілей, які мають значення; активно брати участь у формуванні справедливого та сталого розвитку на нашій планеті. Люди $є$ як споживачами, так і рушійною силою людського розвитку, як окремо так і разом».

Глибинний взаємозв'язок людського розвитку та якості життя полягає, зокрема, людський розвиток спрямовано у тому числі на підвищення якості життя людини. Якість життя відображає базові передумови та ступінь реалізації вимог людського розвитку, ступінь пріоритетності людського розвитку у цивілізаційному процесі, а також самовідчуття людини іiі, самоідентифікацію та стан оточення.

Досягнення високого рівня людського розвитку неможливе без утвердження високої якості життя. Існування обмежень у будь-якій зі сфер соціального буття значно звужує свободу вибору, що становить основу людського розвитку. Зняття обмежень і бар'єрів участі, активізація процесів соціального залучення (інклюзії) 3 метою гарантування найширших можливостей та свобод людей - основне завдання політики людського розвитку, спрямованої також на підвищення якості життя.

Міжнародним співтовариством якість життя визнано однією з головних характеристик рівня суспільного розвитку країн. Поступово відходять у минуле орієнтири переважно на економічні результати та впровадження досягнень науково-технічного прогресу без урахування пріоритетності розвитку людського чинника. Генеральний директор Євростату В. Радермахер у доповіді «Вимірювання добробуту та якості життя» підкреслив, що висока якість життя населення неможлива без покращання здоров'я, забезпечення інтеграції у суспільство, формування сприятливого навколишнього середовища та досягнення мінімального рівня матеріального добробуту. При цьому він відзначив складність процесу оцінювання якості життя, пов'язану, насамперед, із 
формуванням системи індикаторів об'єктивної та суб'єктивної оцінки на міжнародному та національному рівнях.

Генеральний директор Євростату, коментуючи висновки Комісії з вимірювання економічних досягнень і соціального прогресу (Комісія Стігліц-Сен-Фітуссі), акцентував увагу на необхідності покращення інформаційної бази оцінювання якості життя населення на основі залучення різних джерел інформації, визначення індикаторів, найбільш важливих для прийняття управлінських рішень. Важливим завданням також $\epsilon$ узгодження цілей досягнення стабільного економічного зростання та збереження навколишнього середовища, покращення якості освіти, поліпшення здоров'я населення, розвитку соціальної інфраструктури, забезпечення зайнятості та запобігання бідності, підвищення соціальної згуртованості та гарантування демократичних свобод у суспільстві [1].

Процес ринкових трансформацій свідчить про значну залежність рівня довіри громадян до владних інститутів від успіху реформ на шляху забезпечення високої якості життя населення. Саме тому поступово актуалізуються питання розроблення системи оцінювання якості життя населення, що передбачає формування системи індикаторів, які комплексно відображають об'єктивні та суб'єктивні характеристики цього багатокомпонентного поняття.

Дотепер оцінюванню якості життя в Україні не приділялося належної уваги. Однак включення до порядку денного роботи центральних органів виконавчої влади проблематики якості життя, створення Координаційної ради з питань якості і безпеки життя людини (згідно 3 Постановою Кабінету Міністрів України від 26 грудня 2011 р. № 1393) свідчить про поси- лення уваги держави до питань забезпечення належної якості життя людини та реалізації конституційних прав громадян. Моніторинг реалізації завдань поліпшення якості життя населення може бути забезпечено шляхом використання сформованої системи індикаторів оцінювання, розроблення методичних підходів до вимірювання якості життя населення. Це сприятиме визначенню найбільш проблемних сфер та прийняттю ефективних управлінських рішень щодо поліпшення якості життя на національному рівні.

Оцінка ефективності державної політики 3 підвищення якості життя можлива на основі здійснення аналізу значень відповідних індикаторів у часовому (ретроспективному чи прогнозному) або в просторовому (міжтериторіальному) аспектах. У першому випадку це дає змогу оцінити вплив соціально-економічних реформ на рівень життя населення, відстежувати зміни відповідних параметрів якості життя у процесі реалізації програм на національному і регіональному рівнях. У просторовому аспекті - дозволяє виявити міжрегіональні та міжкраїнові відмінності в якості життя населення для визначення орієнтирів державної та регіональної соціально-економічної політики.

Підвищення якості життя людей у поєднанні зі створенням належних умов для реалізації інноваційної моделі економічного зростання, досягнення і перетворення високих стандартів якості життя у потужний чинник глобальної конкурентоспроможності України $\epsilon$ стратегічними управлінськими завданнями. Визначення основних компонентів та чинників впливу на якість життя населення, формування стратегії управління якістю життя дозволить забезпечити гармонізацію цілей економічного зростання, розвитку людини та збереження навколишнього середовища. 


\section{\begin{tabular}{l|l} 
розяп 1 & ТЕОРЕТИЧНІ ЗАСАДИ \\
ВИМІРЮВАННЯ ЯКОСТІ ЖИТТЯ
\end{tabular}}

Узагальнюючи різні трактування якості життя, науковці виокремлюють три основні типи визначень: глобальні, компонентні та вузькі [2]. Згідно з глобальним визначенням, якість життя визначається як ступінь задоволення матеріальних, культурних і духовних потреб людини. Компонентні визначення підкреслюють багатовимірну природу цього поняття і виокремлюють різні виміри якості життя (як об'єктивні, так і суб'єктивні). Згідно із загальноприйнятою позицією, якість життя не лише характеризує умови досягнення та задоволеність умовами (досягненнями), але й враховує можливість збереження досягнутих результатів. Третій підхід до визначення якості життя передбачає вибір лише однієї чи двох категорій та відображення специфічного змісту різних сфер.

Оцінку якості життя можна охарактеризувати як процедуру виявлення ступеня відповідності основних параметрів і умов життєдіяльності людини її життєвим потребам, а також особистим уявленням про гідне життя. Така оцінка здійснюється на основі порівняння характеристик життєдіяльності індивіда або суспільства з відповідними параметрами і характеристиками життя, прийнятими за базу порівняння. Процедура оцінки якості життя складається з низки етапів і операцій: вибір показників якості життя та їх значень, обґрунтування критеріїв оцінки і, нарешті, оцінювання показників якості життя.

Для оцінки якості життя використовуються кількісні, якісні й інтегральні показники. Кількісні показники найбільш очевидні. Насамперед, це ВНП або національний доход на одну особу населення, рівень споживання різних матеріальних благ і послуг за класами товарів, рівень зайнятості тощо. Якісні показники якості життя визначають умови праці, побуту й дозвілля людини. Інтегральні показники якості життя характеризують поєднання її часткових характеристик і критеріїв, причому як кількісних, так і якісних. Вони можуть бути представлені у вигляді різних комбінацій звітних статистичних показників, відповідних експертних оцінок тощо [3].

3 урахуванням ціннісних настанов існуючі концептуальні підходи до оцінювання якості життя можна розділити на два основних напрями: $\checkmark$ об'єктивний підхід дає змогу визначати якість соціального і фізичного (штучного і природного) навколишнього середовища, в якому люди намагаються реалізувати свої потреби;

$\checkmark$ суб'єктивний підхід зосередився на розгляді ціннісних установок. Елементами структури якості життя $\epsilon$ самопочуття, задоволеність життям, щастя (чи комбінація цих елементів).

Об'єктивний підхід $\epsilon$ найбільш поширеним, він визначає якість життя через параметри об'єктивних умов і процесів життєдіяльності. Його мета - вимірювання рівня життя суспільства або групи людей на основі різноманітної статистичної інформації. Об'єктивні параметри оцінки якості життя вимірюються за відповідними методами, що не залежать від ставлення оцінювача до властивостей об'єкта вимірювання та націлені на отримання значень у стандартизованих одиницях вимірювання. Об'єктивна оцінка економічних чинників якості життя охоплює показники матеріального добробуту, середньодушового доходу; середньомісячної заробітної плати, розміру прожиткового мінімуму, чисельності населення з доходами, нижчими за прожитковий мінімум, структури грошових доходів і витрат населення (індекс Джині); забезпеченості житлом тощо.

Суб'єктивний підхід передбачає визначення якості життя на основі соціологічних опитувань. Суб'єктивні оцінки відображають індивідуальне сприйняття індивідом якості життя та ґрунтуються на суб'єктивних відчуттях, особистих оцінках. Більшість дослідників виділяють у суб'єктивних оцінках раціональний і емоційний компоненти. Перший складається із загальної задоволеності життям і оцінок ступеня задоволеності різними сторонами життя. Другий компонент є балансом позитивних і негативних емоцій [4].

Суб'єктивні параметри оцінюються за алгоритмами, що залежать від знань та накопиченого особистого життєвого досвіду, індивідуальних критеріїв оцінювання об'єктів, суб'єктів та явищ, життєвих цінностей і світогляду. Саме 
тому важливим $\epsilon$ вибір критеріїв, за якими індивід повинен оцінювати якість свого життя, методологічний інструментарій узагальнення отриманих висловлювань і оцінок, визначення факторів, здатних впливати на усвідомлення відповідних станів індивіда тощо.

Разом з тим, слід враховувати, що суб'єктивне сприйняття різноманітних компонентів якості життя окремими людьми може дуже різнитися. Так, певні умови забезпечення гідного життя, значущі для одного індивіда, можуть виявитися неважливими або малозначущими для іншого. Через це абсолютно необхідним $є$ визначення, вибір і розмежування критеріїв для порівняння.

Критерії якості життя можуть бути загальними і конкретними. Перші ґрунтуються на ціннісних орієнтаціях щодо змісту якісного життя, які формувалися в суспільстві протягом тривалого часу. Ці критерії, як правило, специфічні для окремих територій, країн, регіонів, соціальних груп та зумовлені поширеними у них особливими традиціями, менталітетом, способами господарювання тощо. Конкретні критерії це еталонні значення визначених показників якості життя. Такими можна вважати результати статистичних обстежень, нормативно або законодавчо визначені норми споживання тощо [5].

Якість життя трактується як головна мета соціально-економічного розвитку та найважливіший критерій ефективності управління економічними процесами та соціальною сферою. Посилення уваги до проблем якості життя населення змушує уряди розвинених країн світу враховувати при розробці стратегії соціальноекономічного розвитку суспільну думку щодо пріоритетів розвитку. Важливо визначити, як впливає суспільство на світогляд та світосприйняття людини, чи $є$ у неї можливість отримувати задоволення від процесу праці, чи може вона розвиватися протягом усього життя та, будучи здоровою, робити значний внесок у загальносуспільний розвиток. Це зумовлює необхідність виявлення взаємозв'язків складових якості життя, нових підходів до створення та використання методів оцінки якості життя людини. 


\section{\begin{tabular}{l|l} 
роздп 2 & $\begin{array}{l}\text { ВИМІРЮВАННЯ ЯКОСТІ ЖИТТЯ: } \\
\text { ІСНУЮЧІ ПІДХОДИ }\end{array}$
\end{tabular}}

\section{1. Міжнародний досвід вимірювання якості життя: можливості міжкраїнових порівнянь}

Актуальність проблем оцінки якості життя підтверджується ініціативами міжнародних організацій, насамперед $\mathrm{OOH}$, урядами країн та експертною спільнотою. Так, за ініціативою Президента Франції було створено Комісію 3 вимірювання економічних досягнень і соціального прогресу, рекомендації якої беруться до уваги у процесах планування та моніторингу.

Певні зобов'язання взято з боку Європейської комісії, у тому числі шляхом встановлення цільових показників розвитку до 2020 року у стратегії Європейського Союзу «Європа 2020: стратегія розумного, сталого й інклюзивного зростання» [25]. Ще у 2007 році на конференції «За межами ВВП», організованої за участю Європейського парламенту, Римського клубу, Європейської комісії, Організації економічного співробітництва та розвитку і Всесвітнього фонду природи, було задекларовано нові підходи до вимірювання суспільного прогресу. Зокрема, президент Європейської комісії Ж. Мануель Баррозу наголосив, що «ВВП безумовно $\epsilon$ дуже цінним інструментом економічної політики, але він не може повністю відобразити все різноманіття та серйозність проблем сучасності. Вирішити проблеми сьогодення і майбутнього неможливо інструментами та підходами минулого. Тому настав час виходити за межі ВВП» [9].

Організацією економічного розвитку та співробітництва (ОЕСР) впроваджується Глобальний проект «Оцінка суспільного прогресу» («Measuring the progress of societies»), діяльність якого спрямована на підвищення інформованості, мобілізацію політичної підтримки для оцінювання прогресу та розвиток системи ключових економічних, соціальних та екологічних індикаторів. У ході зустрічі лідерів «великої двадцятки» у Пітсбургу у 2009 р. було особливо наголошено на абсолютній необхідності розробки та практичного освоєння нових методів вимірювання суспільного прогресу, що враховували 6 соціальні й екологічні аспекти при формуванні напрямів забезпечення збалансованого зростання.
Вимірюванню суспільного прогресу було присвячено роботу Всесвітнього форуму зі статистики, знань та політики, який проходив у Стамбулі у червні 2007 р. У його роботі взяли участь понад 1200 представників різних урядів, бізнесменів, лідерів громадянського суспільства, науковців зі 130 країн. Підсумком роботи Форуму стала Стамбульська декларація, підписана представниками Європейської комісії, Світовим банком, Організацією економічного співробітництва та розвитку, Організацією Об'єднаних Націй і їі численних інституцій та низкою інших експертних міжнародних груп. У ході дискусії підписанти декларації визначили за необхідне відповісти на такі першочергові запитання [6]:

$\checkmark$ що вимірювати? Питання акцентує увагу на необхідності визначити, що $\epsilon$ об'єктом вимірювання: або ресурси і умови, або продукти і результати, а також на потребі чіткого бачення чинників розвитку. I, нарешті, - на необхідності знати, до чого прагнути, що $є$ прогрес;

$\checkmark$ як вимірювати? Питання загострює увагу на тому, що існують серйозні методологічні проблеми з оцінюванням прогресу у таких сферах, як безпека, права людини, громадська участь, участь у суспільному житті та деяких інших;

$\checkmark$ які критерії класти в основу процесу вимірювання? Питання зосереджує інтерес до того, що повинно бути пріоритетом: оцінка досягнень чи, навпаки неможливість задоволення потреб; прогрес чи регрес; як урахувати упущені вигоди й екстерналії;

$\checkmark$ на якому рівні організувати вимірювання? Питання закликає визначити, який рівень аналізу має переважати: індивідуальний рівень, рівень домогосподарства, сім'ї, громади, регіону, країни тощо;

$\checkmark$ для чого вимірювати? Питання наголошує на потребі визначення ієрархії цілей оцінювання: оцінювання результативності публічної політики, оцінювання для прийняття управлінських рішень, оцінювання для стратегічного планування, оцінювання для здійснення міжнародних порівнянь тощо.

Підписанти Декларації закликали експертів використовувати існуючі національні та міжнародні статистичні дані й соціологічні матеріали при розробленні підходів до вимірювання суспіль- 
ного прогресу та розробляти рекомендації щодо прийняття важливих управлінських рішень. Адже оцінка якості життя населення $\epsilon$ важливим інструментом соціально-економічної політики будь-якої держави, тому що дозволяє: встановлювати орієнтири соціально-економічної політики на перспективу; здійснювати аналіз поточного рівня соціально-економічного розвитку країни; оцінювати рівень бідності; визначати місце країни у загальносвітовому прогресі; проводити міжрегіональні порівняння рівня та якості життя населення [7].
Для оцінки якості життя населення, як правило, використовують два підходи, мета і призначення яких різні. При першому підході оцінка якості життя проводиться для міжнародних порівнянь з різними країнами світу. При другому оцінюється якість життя населення на рівні країни для прийняття урядом рішень щодо планування їі соціально-економічного розвитку [8].

Наразі державними та приватними установами розроблено більше 150 композиційних індикаторів добробуту для оцінки ефективності

Таблиця 2.1 - Загальна характеристика міжнародних систем оцінювання якості життя

\begin{tabular}{|c|c|c|c|c|}
\hline Назва & $\begin{array}{c}\text { Суб'єкт, } \\
\text { який здійснює } \\
\text { розрахунок }\end{array}$ & $\begin{array}{c}\text { Принцип } \\
\text { розрахунку }\end{array}$ & Індикатори & $\begin{array}{l}\text { Кількість } \\
\text { охоплених } \\
\text { країн }\end{array}$ \\
\hline 1 & 2 & 3 & 4 & 5 \\
\hline $\begin{array}{l}\text { Загально- } \\
\text { методологічна } \\
\text { концепція } \\
\text { стандартів і } \\
\text { якості життя }\end{array}$ & $\begin{array}{l}\text { Науково- } \\
\text { академічне } \\
\text { співтова- } \\
\text { риство в } \\
\text { цілому }\end{array}$ & $\begin{array}{l}\text { Розмежування } \\
\text { макроекономіч- } \\
\text { них показників } \\
\text { та соціологічних } \\
\text { індикаторів }\end{array}$ & $\begin{array}{l}\text { ВВП на одну особу населення, } \\
\text { індекс споживчих цін, споживчий } \\
\text { кошик, видатки домогосподарств, } \\
\text { GFK кошик, рівень бідності, } \\
\text { нерівність у доходах, задоволеність } \\
\text { життям і щастя, депривація, } \\
\text { оптимізм щодо майбутнього тощо }\end{array}$ & $\begin{array}{l}\text { Залежно } \\
\text { від } \\
\text { академіч- } \\
\text { них за- } \\
\text { вдань }\end{array}$ \\
\hline $\begin{array}{l}\text { Індекс якості } \\
\text { життя EIU }\end{array}$ & $\begin{array}{l}\text { Дослідницька } \\
\text { організація } \\
\text { Economic } \\
\text { Intelligence } \\
\text { Unit }\end{array}$ & $\begin{array}{l}\text { Рівнозначне } \\
\text { врахування } \\
\text { кількісних і } \\
\text { суб'єктивних } \\
\text { показників }\end{array}$ & $\begin{array}{l}\text { Здоров'я, сім'я, громадське життя, } \\
\text { матеріальне благополуччя, полі- } \\
\text { тична стабільність і безпека, клімат, } \\
\text { гарантія зайнятості, політична сво- } \\
\text { бода, гендерна рівність }\end{array}$ & 111 \\
\hline $\begin{array}{l}\text { Методологія } \\
\text { ЄC European } \\
\text { Statistical } \\
\text { System } \\
\text { Committee }\end{array}$ & $\begin{array}{l}\text { Європейський } \\
\text { комітет статис- } \\
\text { тичних систем }\end{array}$ & $\begin{array}{l}\text { Рівнозначне } \\
\text { врахування } \\
\text { кількісних і } \\
\text { суб'єктивних } \\
\text { показників }\end{array}$ & $\begin{array}{l}\text { Матеріально-побутові умови, про- } \\
\text { дуктивна чи основна активність, } \\
\text { здоров'я, освіта, дозвілля (відпо- } \\
\text { чинок) та соціальні комунікації } \\
\text { (взаємодія), економічна та фізична } \\
\text { безпека, державне управління (вла- } \\
\text { да) та основні права, природа та } \\
\text { навколишнє середовище, загальне } \\
\text { сприйняття життя }\end{array}$ & \\
\hline $\begin{array}{l}\text { Індекс якос- } \\
\text { ті життя } \\
\text { International } \\
\text { Living }\end{array}$ & $\begin{array}{l}\text { Журнал } \\
\text { International } \\
\text { Living }\end{array}$ & $\begin{array}{l}\text { Рівнозначне } \\
\text { врахування } \\
\text { кількіснихі } \\
\text { суб'єктивних } \\
\text { показників }\end{array}$ & $\begin{array}{l}\text { Вартість життя, культура, еконо- } \\
\text { міка, довкілля, свобода, здоров'я, } \\
\text { інфраструктура, безпека та ризик, } \\
\text { клімат }\end{array}$ & 190 \\
\hline $\begin{array}{l}\text { Європейський } \\
\text { моніторинг } \\
\text { якості життя }\end{array}$ & $\begin{array}{l}\text { Європейська } \\
\text { фундація } \\
\text { покращення } \\
\text { життя та умов } \\
\text { праці }\end{array}$ & $\begin{array}{l}\text { Соціологічне } \\
\text { обстеження } \\
\text { якості життя }\end{array}$ & $\begin{array}{l}\text { Здоров'я, зайнятість, депривації (по- } \\
\text { збавлення) за доходами, освіта, сім'я, } \\
\text { соціальна участь, житло, навколишнє } \\
\text { середовище, транспорт, безпека, від- } \\
\text { починок, задоволеність життям }\end{array}$ & 34 \\
\hline $\begin{array}{l}\text { Better Life } \\
\text { Initiative }\end{array}$ & OECP & $\begin{array}{l}\text { Інтегральна } \\
\text { оцінка } \\
\text { параметрів }\end{array}$ & $\begin{array}{l}\text { Житлові умови, доходи, зайнятість, } \\
\text { освіта, екологія, здоров'я, ефектив- } \\
\text { ність управління, суспільне життя, } \\
\text { безпека, задоволеність умовами } \\
\text { життя, баланс між робочим часом і } \\
\text { дозвіллям }\end{array}$ & 34 \\
\hline
\end{tabular}


діяльності урядів різних країн в економічній, соціальній та екологічній сфері на міжнародному рівні. Існує більше сотні ініціатив щодо використання показників якості життя у процесі прийняття рішень на національному й місцевому рівні.

Показники, за допомогою яких оцінюється рівень і якість життя на міжнародному рівні, можна розділити на кількісні та якісні: кількісні включають ВНП або національний дохід на одну особу населення, рівень доходу та його розподіл в суспільстві, рівень споживання різних матеріальних благ і послуг за класами товарів, рівень зайнятості і т. ін. Якісні показники якості життя включають показники умов праці, побуту і дозвілля людини тощо.

Необхідно зазначити, що кількісні індикатори необхідні для оцінки об'єктивних сторін якості життя. Однак неможливо оцінювати досягнення суспільного прогресу лише з використанням кількісних (економічних) показників, незважаючи на відносну простоту їх збирання та інтерпретації.

На поточний момент не існує єдиного підходу до оцінки якості життя населення. Різноманіття підходів до вимірювання якості життя узагальнено в табл. 2.1.

Загальнометодологічна концепція стандартів і якості життя (Standard of Living and Quality of Life) використовується для оцінки суспільного прогресу у різних країнах. Концепція передбачає розмежування та оцінювання окремо двох елементів суспільного прогресу: рівня життя i якості життя. Згідно з концепцією стандартів і якості життя, складова стандартів життя відображає економічні (переважно макроекономічні) та інші об'єктивні показники [7], тоді як складова якості життя - переважно соціологічні або показники суто соціального змісту (здебільшого, суб'єктивні). Вказана методологія не має чіткого переліку показників для оцінювання і застосовується довільно, водночас для міжнародних порівнянь вона може використовуватися точково і частково [10].

Сегмент економічних індикаторів включає показник ВВП на одну особу населення, індекс споживчих цін, споживчий кошик, видатки домогосподарств, GFK кошик, рівень бідності, нерівність у доходах тощо. Суб'єктивні показники - це ступінь задоволеності життям і відчуття щастя, суб'єктивна оцінка ступеня власної депривації, оптимізм щодо майбутнього тощо [11].

Методологія Economist Intelligence Unit (підрозділу The Economist Group) передбачає розрахунок відповідного Індексу якості життя для 111 країн світу за регресійною моделлю, котра переважно (на 80\%) заснована на результатах соціологічних опитувань. Поряд із суб'єктивними оцінками якості життя, одержаними за результатами опитувань респондентів різного віку, що ранжували ступінь задоволеності різноманітними сферами якості життя за 5-бальною шкалою, у цій методології враховано окремі об'єктивні детермінанти. Найбільшу увагу було приділено розрахункам ВВП на одну особу населення за паритетами купівельної спроможності.

Для визначення рейтингу країни дослідження оцінює якість життя за дев'ятьма напрямами (Здоров'я, Сім'я, Громадське життя, Добробут за матеріальною ознакою, Політична стабільність і безпека, Клімат, Гарантії зайнятості, Політична свобода, Гендерна рівність), вимірювання яких опосередковане відповідними індикаторами (Додаток А). Ці індикатори входять до Індексу, і їх значущість враховується відповідно до ваг, що визначаються на основі застосування коефіцієнтів багатофакторної регресії.

Нова європейська стратегія розвитку на наступні 10 років - «Європа 2020: Стратегія розумного, сталого і інклюзивного зростання», прийнята Радою ЄС у 2010 році та базується на здійсненні аналізу моніторингу якості життя населення країн ЄС. Згідно зі Стратегією 2020, визначаються три найважливіших напрями зростання: Розумне зростання (розвиток економіки, що базується на знаннях та інноваціях), Стійке зростання (створення економіки, що передбачає раціональне використання ресурсів, зеленої економіки); Інклюзивне зростання (соціальна інклюзія, підвищення рівня зайнятості населення, досягнення соціального та територіального узгодження).

Після проведення конференції «За межами ВВП» поступово актуалізувалося питання розробки набору індикаторів для аналізу якості життя у країнах-членах ЄС. У 2011 році Європейський комітет статистичних систем (European Statistical System Committee - ESSC) прийняв рішення щодо розробки відповід- 
ного набору показників для країн-членів $\in C$ (табл. 2.2). Наразі зроблена лише перша спроба щодо об'єднання даних із декількох джерел для вимірювання якості життя в $\in C$ за такими напрямами: 1) Матеріальнопобутові умови; 2) Продуктивна чи основна активність; 3) Здоров'я; 4) Освіта; 5) Дозвілля (відпочинок) та соціальні комунікації (взаємодія); 6) Економічна та фізична безпека; 7) Державне управління (влада) та основні права; 8) Природа та навколишнє середовище; 9) Загальне сприйняття життя (Додаток Б).

Методологія International Living (Ірландія) оцінювання якості життя населення використовується для дослідження прогресу у 190 країнах світу. Відповідно до цієї методики, розраховуються індекси за дев'ятьма основними напрямами: 1) Прожитковий мінімум (вартість життя); 2) Культура; 3) Економіка; 4) Навколишн $\epsilon$ середовище; 5) Свобода; 6) Здоров'я; 7) Інфраструктура; 8) Безпека i ризик; 9) Клімат (Додаток В). Можливий максимальний бал за кожним критерієм становить 100. Щорічно публікується світовий рейтинг.

Методологія $\in C$ передбачає здійснення моніторингу якості життя населення у країнах $\in C$ Європейським фондом з питань покращення життя таумов праці (European Foundation for the Improvement of Living and Working Conditions), який заснований у 2000 році (Дублін, Ірландія). Ця організація із чотирирічним інтервалом збирає, аналізує, публікує і поширює дані стосовно 27 країн-членів $\in C$ і 2 країн-кандидатів (Хорватія, Туреччина) за 160 показниками, які диференційовано на 12 груп за напрямами: 1) Здоров'я, 2) Зайнятість, 3) Доходи, 4) Освіта, 5) Сім'я, 6) Громадське життя, 7) Житлові умови, 8) Навколишнє середовище, 9) Транспорт, 10) Безпека, 11) Відпочинок, 12) Задоволеність життям (Додаток Г).

Моніторинг якості життя населення $\in С$ базу$\epsilon$ ться на суб'єктивних оцінках і $\epsilon$ альтернативним джерелом даних, оскільки доповнює об'єктивну оцінку, що базується на даних Євростату. Статистика $\in С$ стосовно питань доходів та умов життя (European Union Statistics on Income and Living Conditions, EU-SILC) застосовується для оцінки якості та рівня життя, для здійснення міжкраїнових зіставлень, порівняння кращих практик та вимірювання суспільного прогресу. При цьому соціальне залучення виступає одним з пріо- ритетних напрямів політики $\in C$, оскільки на якість життя населення впливає незадоволеність життям соціально відторгнених груп населення.

Методологія ОЕСР (Організації економічного співробітництва та розвитку) базується на інноваційній платформі Better Life Initiative, що презентує результати оцінки якості життя безпосередньо громадянами 34 країн в інтерактивному режимі за 11-ми основними напрямами: 1) Доходи; 2) Праця; 3) Баланс праці та відпочинку; 4) Здоров'я; 5) Освіта; 6) Житлові умови; 7) Громада; 8) Участь у суспільному житті; 9) Навколишнє середовище; 10) Безпека; 11) Задоволеність життям (Додаток Д). Вказана методологія передбачає конструювання індивідуальних індексів якості життя кожним респондентом, який згодився взяти участь в інтерактивному опитуванні [12].

Показники для методології відібрано з урахуванням низки статистичних критеріїв, таких як актуальність і якість даних (достовірність прогнозу, охоплення, своєчасність, порівнянність між країнами), та в ході проведення консультацій з країнами - членами ОЕСР.

Найважливішим досягненням розробників інтерактивного обстеження Better Life Initiative можна вважати створення адекватної, доступної та порівнюваної бази даних для користувачів, що дає можливість кращого розуміння чинників впливу на якість життя населення. Аналіз відповідей респондентів дозволяє фахівцям ОЕСР формулювати обгрунтовані та доцільні рекомендації щодо напрямів покращення якості життя політикам і державним менеджерам.

\section{2. Підходи до вимірювання якості життя населення в окремих країнах}

Національні системи оцінки якості життя, зберігаючи загалом можливості для міжнародних порівнянь, ураховують специфіку сучасного розвитку та історичне минуле кожної конкретної країни. Також більш повно та інформативно ці системи відображають актуальні потреби ії громадян, визначають економічний, соціальний, екологічний, духовний контекст їх життєдіяльності.

Різноманіття підходів окремих країн до вимірювання якості життя узагальнено в табл. 2.2. 
Таблиця 2.2 - Напрями та індикатори вимірювання якості життя в окремих країнах

\begin{tabular}{|c|c|c|}
\hline Країна & Напрями оцінювання & Кількість індикаторів оцінювання \\
\hline 1 & 2 & 3 \\
\hline $\begin{array}{l}\text { Нова } \\
\text { Зеландія }\end{array}$ & $\begin{array}{l}\text { Одинадцять напрямів оціню- } \\
\text { вання: } \\
\text { рівень життя; економічний } \\
\text { розвиток; населення; здоров'я; } \\
\text { знання і вміння; навколишнє } \\
\text { середовище; безпека; житлові } \\
\text { умови; міський спосіб життя; } \\
\text { громадянські й політичні пра- } \\
\text { ва; соціальні мережі }\end{array}$ & 68 ключових індикаторів (186 одиничних показників) \\
\hline $\begin{array}{l}\text { Велика } \\
\text { Британія }\end{array}$ & $\begin{array}{l}\text { Чотирнадцять напрямів оці- } \\
\text { нювання: } \\
\text { економічна ефективність } \\
\text { інвестиції; зайнятість; бідність } \\
\text { і соціальне відторгнення; } \\
\text { освіта; здоров'я; житло; } \\
\text { рівень злочинності; зміна } \\
\text { клімату; якість повітря; } \\
\text { безпека дорожнього } \\
\text { руху; якість річкової води; } \\
\text { дика природа; параметри } \\
\text { землекористування; відходи }\end{array}$ & 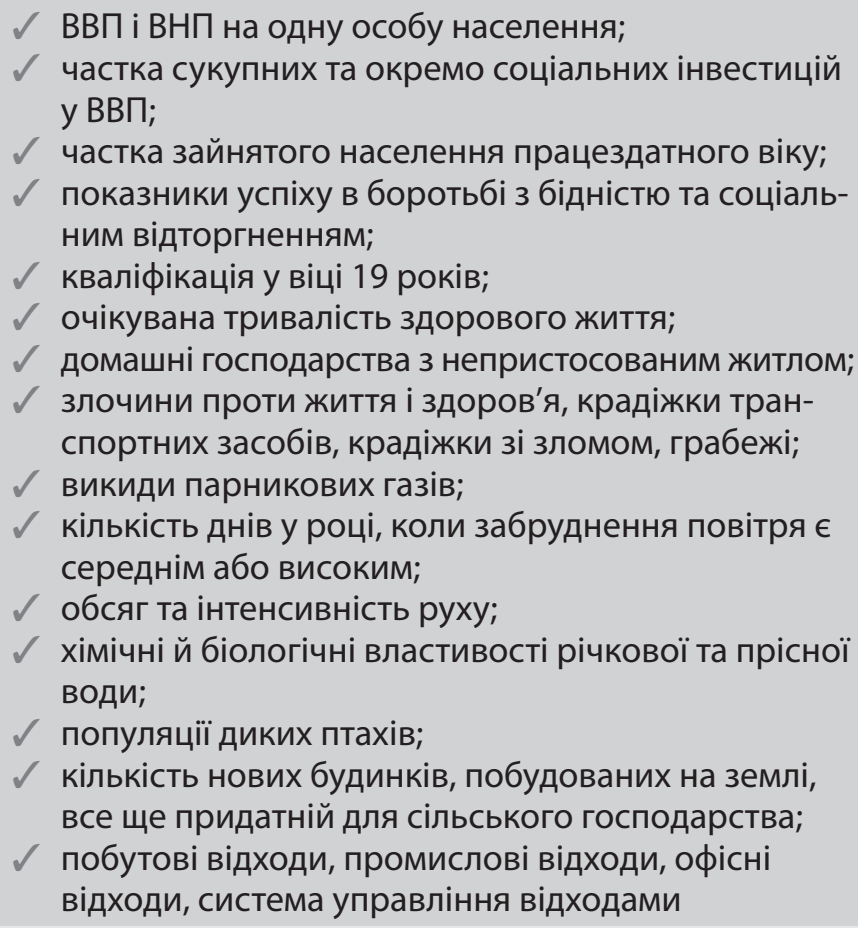 \\
\hline Канада & $\begin{array}{l}\text { Канадський індекс благо- } \\
\text { получчя (Сanadian Index of } \\
\text { Wellbeing) розраховується за } \\
8 \text { напрямами: } \\
\checkmark \text { громадське життя; } \\
\checkmark \text { демократична участь; } \\
\checkmark \text { освіта; } \\
\checkmark \text { довкілля; } \\
\checkmark \text { здоров'я, } \\
\checkmark \text { дозвілля і культура; } \\
\checkmark \text { рівень життя; } \\
\checkmark \text { використання часу }\end{array}$ & 64 показники \\
\hline $\begin{array}{l}\text { Сполучені } \\
\text { Штати } \\
\text { Америки }\end{array}$ & $\begin{array}{l}13 \text { напрямів оцінювання: рі- } \\
\text { вень життя; зайнятість; умови } \\
\text { праці; демографічна ситуація; } \\
\text { охорона здоров'я; освіта; } \\
\text { навколишнє середовище; } \\
\text { соціальне забезпечення; жит- } \\
\text { лові умови; культура; відпо- } \\
\text { чинок і розваги; транспортне } \\
\text { забезпечення; національна } \\
\text { оборона; правовий захист }\end{array}$ & \\
\hline
\end{tabular}


Продовження табл. 2.2.

\begin{tabular}{|c|c|c|}
\hline 1 & 2 & 3 \\
\hline $\begin{array}{l}\text { Російська } \\
\text { Федерація } \\
\text { (за мето- } \\
\text { дикою ака- } \\
\text { деміка РАН } \\
\text { С.А. Айвазя- } \\
\text { на) }\end{array}$ & $\begin{array}{l}\text { Інтегральний індекс розрахо- } \\
\text { вується за 5-ма напрямами: } \\
\checkmark \\
\text { якість населення; } \\
\checkmark \text { добробут населення; } \\
\checkmark \text { соціальна безпека (якість } \\
\text { соціальної сфери); } \\
\checkmark \text { якість навколишнього } \\
\text { середовища; } \\
\checkmark \\
\text { природно-кліматичні } \\
\text { умови }\end{array}$ & $\begin{array}{l}300 \text { показників: } \\
\checkmark \text { очікувана тривалість життя, рівень освіти, кваліфіка- } \\
\text { ція, народжуваність і смертність, шлюбність тощо; } \\
\checkmark \text { реальні доходи, їх диференціація, рівень спожи- } \\
\text { вання товарів і послуг, рівень забезпечення потуж- } \\
\text { ностями інфраструктури суспільства тощо; } \\
\checkmark \text { рівень умов праці, соціального захисту, фізичної та } \\
\text { майнової безпеки члена суспільства, криміноген- } \\
\text { ного і соціально-політичного здоров'я самого су- } \\
\text { спільства тощо; } \\
\checkmark \\
\text { дані про забруднення повітряного простору, води, } \\
\text { про якість ґрунту, рівень біорізноманіття тощо; } \\
\checkmark \\
\text { склад і обсяги природно-сировинних ресурсів, } \\
\text { клімату }\end{array}$ \\
\hline $\begin{array}{l}\text { Республіка } \\
\text { Беларусь } \\
\text { (регіональний } \\
\text { інтегральний } \\
\text { індекс якості } \\
\text { життя насе- } \\
\text { лення) }\end{array}$ & $\begin{array}{l}\text { П'ять базових компонентів } \\
\text { якості життя: якість } \\
\text { населення; рівень життя } \\
\text { населення; якість соціальної } \\
\text { сфери; духовний та } \\
\text { культурний стан суспільства } \\
\text { та якість екосистеми }\end{array}$ & 38 статистичних показників \\
\hline
\end{tabular}

у Новій Зеландії з кінця 1990-х років реалізується національний проект «Якість життя», мета якого - забезпечення владних органів та урядових інституцій інформацією і даними про якість життя населення. Проект був ініційований у відповідь на зростаючий тиск на міські громади, стурбованість з приводу наслідків урбанізації та її впливу на добробут жителів [13].

Соціологічне обстеження якості життя у рамках Проекту проводиться раз на два роки, починаючи 32004 р. Статистичний моніторинг на основі даних урядових інституцій та бюро статистики здійснюється постійно. У цілому система показників охоплює 68 ключових індикаторів (186 одиничних показників), які класифіковані за одинадцятьма напрямами: 1) Рівень життя; 2) Економічний розвиток; 3) Населення; 4) Здоров'я; 5) Знання і вміння; 6) Навколишнє середовище; 7) Безпека; 8) Житлові умови; 9) Міський спосіб життя; 10) Громадянські й політичні права; 11) Соціальні мережі.

За напрямом рівня життя аналізуються дохід, баланс праця - життя; вартість проживання, соціальне відторгнення; чиста вартість активів (активи і зобов'язання). Напрям економічного розвитку містить показники економічного зростання, зайнятості, розвитку сфери досліджень та науково-технічних розробок, розвитку місцевих підприємства, обсяги роздрібних продажів, використання житлових та нежит- лових будівель, розвитку туризму, кваліфікації мігрантів.

Демографічний напрям відображає особливості зростання чисельності населення, враховує етнічний склад, віковий склад, конфігурацію сім'ї та склад домогосподарства, ступінь інвалідизації населення, добробут корінного населення. Напрям здоров'я досліджує очікувану тривалість життя, випадки низької ваги при народженні дітей, дитячу смертність, підліткове батьківство, поширеність хвороб, доступність послуг лікаря загальної практики, психічне й емоційне благополуччя, самооцінку стану здоров'я, фактори ризику, випадки узалежнення (алкогольне, наркологічне), відпочинок та дозвілля. Напрям знань і вмінь передбачає аналіз показників залучення до дошкільної і шкільної освіти, характеристику кваліфікаційних рівнів, навиків, дослідження рівня відповідності професії/посаді (job match), можливостей і стану професійного навчання.

Екологічний напрям бере до уваги місцеві екологічні проблеми, управління відходами, біорізноманіття, використання енергії, якість повітря, якість водойм і якість пляжної інфраструктури, якість питної води, охорону водних ресурсів. Напрям безпеки аналізує сприйняття безпеки, безпеку дітей, ризик травм, безпеку дорожнього руху, безпеку на робочому місці, рівень злочинності. 
Житловий напрям оцінює володіння нерухомістю, витрати на житло, щільність забудови, надання соціального житла за державний кошт, доступність житла (невартісні чинники). Напрям, що містить характеристики міського способу життя, включає оцінку зовнішнього вигляду міста, землекористування, інтенсивності руху і якості транспорту, якості громадського транспорту, доступу до послуг, комфортності 3 огляду на щільність населення.

За напрямом громадянських і політичних прав вивчаються участь населення в ухвалення рішень місцевою владою, явка виборців, представництво різних категорій і верств населення у виборних органах. Напрям соціальних мереж містить індикатори щодо загальної оцінки якості життя, різноманітності й ідентичності, наявність «духу громади» та міцності місцевого співтовариства, використання електронних засобів комунікації, захоплення мистецтвом та розвиток культури.

У Великій Британії у межах стратегії сталого розвитку країни уряд ініціював здійснення моніторингу якості життя, використовуючи п'ятнадцять груп показників, які були узгоджені 3 представниками громадськості, бізнесу та екологічним співтовариством. У щорічних публікаціях звіту «Якість життя» (QoLC) Індикатори стратегії сталого розвитку для Сполученого Королівства, починаючи з 1999 р., відображаються такі аспекти оцінювання якості життя, як: економічна ефективність (ВВП і ВНП на одну особу населення); інвестиції (частка сукупних та окремо соціальних інвестицій у ВВП); зайнятість (частка зайнятого населення працездатного віку); бідністьі соціальне відторгнення (показники успіху в боротьбі з бідністю та соціальним відторгненням); освіта (кваліфікація у віці 19 років); здоров'я (очікувана тривалість здорового життя); житло (домашні господарства, які живуть у непристосованому житлі); рівень злочинності (злочини проти життя і здоров'я, крадіжки транспортних засобів, крадіжки зі зломом, грабежі); зміна клімату (викиди парникових газів); якість повітря (кількість днів у році, коли забруднення повітря $\epsilon$ середньою або високою); безпека дорожнього руху (обсяг та інтенсивність руху); якість річкової води (хімічні і біологічні властивості річкової та прісної води); дика природа (популяції диких птахів); параметри землекористування (кількість нових будинків, побудованих на землі, все ще придатній для сільського господарства); відходи (побутові відходи, промислові відходи, офісні відходи, система управління відходами) [14].

3-поміж національних ініціатив вимірювання та оцінювання якості життя виділяється Канадський індекс благополуччя (Canadian Index of Wellbeing), розроблений фахівцями факультету прикладних наук про здоров'я Університету Ватерлоо. Нині Індекс підтриму$\epsilon$ ться незалежною, безпартійною групою національних та міжнародних лідерів, учених, організацій і пересічних громадян.

Основна ціль розрахунку Індексу - поліпшення системи збирання та оброблення даних для соціальних, економічних та екологічних змінних, відстеження їх динаміки, поглиблення статистичних знань громадян та підвищення рівня володіння статистичною інформацією державними діячами. Значний період (фактично з 1994 р.) моніторингу якості життя в Канаді надав можливість нагромадити серйозний досвід застосування індикаторів якості життя у державному менеджменті [15].

Індекс розраховується на основі 64 показників за 8 секціями:

$\checkmark$ громадське життя;

$\checkmark$ демократична участь;

$\checkmark$ освіта;

$\checkmark$ довкілля;

$\checkmark$ здоров'я;

$\checkmark$ дозвілля і культура;

$\checkmark$ рівень життя;

$\checkmark$ використання часу.

У секції громадського життя аналізуються 23 показника, однак до Індексу включаються 11, що відображають такі аспекти: участь у громадській діяльності, волонтерство, кількість близьких родичів, надання благодійної допомоги, злочини проти власності, злочини проти життя і здоров'я, можливість самотніх прогулянок після настання темряви, довіра, досвід дискримінації, турбота про інших, належність до спільноти.

у секції демократичної участі аналізуються 74 актуальні показники, до складу Індексу включено лише вісім: відсоток явки на федеральному голосуванні; відсоток тих, хто взагалі не цікавиться політикою; відсоток абсолютно згодних з тим, що голосування на федеральних виборах $\epsilon$ обов'язком громадян; відсоток абсолютно або достатньо задоволених тим, 
як демократія працює в Канаді; відсоток тих, хто висловлює високу або достатню довіру до федерального Парламенту; співвідношення зареєстрованих виборців і тих, хто має право голосу; частка жінок у Парламенті; чиста 30внішня допомога у відсотках від валового національного доходу.

Секція освіти Індексу вимірює рівень освіченості та кваліфікації населення, в тому числі здатність дітей і дорослих функціонувати в різних соціальних контекстах. Вона враховує такі аспекти: дошкільна освіта і догляд; розвиток охорони здоров'я в закладах дошкільної освіти; забезпеченість педагогами в державних школах з огляду на кількість школярів; соціальні й емоційні компетенції у шкільному віці; основні знання та навички молоді; рівність в освіті; відсоток осіб із завершеною шкільною освітою; вища освіта.

Секція довкілля оцінює стан і тенденції в галузі навколишнього середовища Канади з огляду на запаси та потоки «екологічних» товарів і послуг. Секція містить п'ять груп показників щодо: якості повітря; виробництва енергії; якості питної води; споживання невідновлюваних ресурсів, включаючи енергоносії та метали й оцінку рівня утилізації відходів; споживання біотичних ресурсів (територіальних і акваторіальних).

Секція здоров'я оцінює стан фізичного, психічного і соціально-психологічного здоров'я населення. До секції включено вісім груп індикаторів, що характеризують: суб'єктивну самооцінку стану здоров'я; тривалість життя і смертність (очікувана тривалість життя при народженні; коефіцієнт дитячої смертності; смертність внаслідок випадкових травм); фізичний стан здоров'я (поширеність діабету; поширеність ожиріння; низька вага при народженні; поширеність астми); очікувану тривалість життя, скориговану на стан здоров'я; параметри способу життя і поведінки (куріння; фізична активність); стан психічного здоров'я (ймовірний ризик розвитку депресії; самооцінка психічного здоров'я); параметри системи охорони здоров'я (задоволеність пацієнтів рівнем надання медичних послуг; частка населення, що регулярно користується послугами сімейного лікаря); ризик захворіти, відвідуючи громадські місця (рівень імунізації проти грипу).

Секція дозвілля і культури охоплює чотири аспекти: відпочинок, мистецтво і культурна діяльність; суб'єктивні сприйняття дозвілля і культури, в тому числі мотиви та потреби; дозвілля та культура як цінності та їх відображення у свідомості осіб; можливості, що надаються для проведення якісного дозвілля та розвитку культури. Показники у компоненті дозвілля і культури включають: відсоток часу, присвячений напередодні дозвіллю; відсоток часу, присвячений напередодні мистецтву та культурній діяльності; середня кількість годин у минулому році, присвячених волонтерській участі в організаціях культури і дозвілля; фізична активність тривалістю більше 15 хвилин протягом місяця; відвідуваність розважальних та культурних заходів в минулому році; відвідуваність національних парків та історичних пам'яток; середня кількість ночівель поза домом протягом відпустки в минулому році; витрати минулого року за всіма аспектами культури і відпочинку у відсотках до загального обсягу витрат домогосподарств.

Секція рівня життя оцінює рівень і розподіл доходів та багатства у суспільстві, в тому числі тенденції поширення бідності, регулярність доходів, ступінь економічної безпеки, включаючи безпеку робочих місць, забезпеченість продовольством, якість житла і рівень соціального забезпечення. Індикатори рівня життя включають: співвідношення верхнього та нижнього квінтиля домогосподарств за доходами після оподаткування; медіанний дохід сім'ї після сплати податків; частку осіб з низьким доходом; індекс економічної безпеки (розраховується Центром життєвих стандартів); частку тривало безробітних осіб; відсоток зайнятої робочої сили; індекс якості зайнятості (розраховується Канадським Імперським Комерційним Банком); індекс доступності житла (розраховується Королівським Банком Канади).

Секція використання часу описує способи використання часу, фактори, що впливають на обрання індивідом того чи іншого способу використання часу, а також вплив цих рішень на благополуччя індивіда. У секції показники диференціюються за соціально-віковими групами. Для осіб у працездатному віці розраховується: частка нестандартних робочих годин (нічних тощо); тривалість робочого часу; робочий стрес, викликаний часовим чинником; час, витрачений на догляд за літніми людьми. Для пенсіонерів - час активного відпочинку; час, присвячених волонтерській діяльності. Для дітей та підлітків - час, проведений перед те- 
леекраном чи за комп'ютером; участь в організованих позакласних заходах; час, проведений разом з батьками; час спільного з батьками прийому їжі вдома (спільний домашній обід чи вечеря) [16].

у Сполучених Штатах Америки теж накопичено чималий досвід аналізу та вимірювання різноманітних аспектів якості життя населення. На федеральному рівні якість життя оцінюється за 13 категоріями: рівень життя, зайнятість, умови праці, демографічна ситуація, охорона здоров'я, освіта, навколишнє середовище, соціальне забезпечення, житлові умови, культура, відпочинок і розваги, транспортне забезпечення, національна оборона, правовий захист.

Дослідження останніх 20 років у США, що базуються на даних Bureau of Labour Statistics та суб'єктивних оцінках, розкрили зв'язок якості життя, особистісного статусу і цінностей індивідів, який слід ураховувати при оцінці якості життя. Статусні індикатори, що стосуються якості життя, такі: 1) Дохід, пов'язаний з суб'єктивними й об'єктивними вимірами якості життя; 2) Зайнятість; 3) Вік; 4) Гендер; 5) Шлюбний статус; 6) Етнічність; 7) Місце проживання (місто-село); 8) Здоров'я; 9) Зовнішність [13].

У Російській Федерації на сьогодні розроблено й застосовуються кілька десятків внутрішніх систем показників для оцінки якості життя населення країни або її окремих регіонів. Однією 3 найбільш широко застосовуваних методик $\epsilon$ розрахунок Інтегрального індикатора якості життя (IIKЖ), розроблений фахівцями Центрального економіко-математичного інституту Російської академії наук під керівництвом С. А. Айвазяна. Перевагою цього підходу до побудови інтегрального індикатора якості життя населення $\epsilon$ те, що він дозволяє провести оцінку на основі офіційних даних органів державної статистики [17].

Підхід заснований на спеціальних процедурах агрегування одиничних (статистично зареєстрованих) показників за різноманітними аспектами якості життя. Всі елементи, які формують середовище і систему забезпечення життєдіяльності населення, об'єднані у п'ять інтегральних груп:

$\checkmark$ якість населення, що інтегрує такі його властивості, як очікувана тривалість життя, рівень освіти, кваліфікація, народжуваність і смертність, шлюбність тощо;

$\checkmark$ добробут населення, що інтегрує основні показники рівня життя та відображає ступінь задоволення його матеріальних і духовних потреб населення (реальні доходи, їх диференціація, рівень споживання товарів і послуг, рівень забезпечення потужностями інфраструктури суспільства тощо);

$\checkmark$ соціальна безпека (якість соціальної сфери), що відображає рівень умов праці, соціального захисту, фізичної та майнової безпеки члена суспільства, криміногенного і соціально-політичного здоров'я самого суспільства тощо;

$\checkmark$ якість навколишнього середовища (якість екологічної ніші), що акумулює дані про забруднення повітряного простору, води, про якість ґрунту, рівень біорізноманіття тощо;

$\checkmark$ природно-кліматичні умови, що характеризуються складом і обсягами природносировинних ресурсів, кліматом, частотою і специфікою форс-мажорних ситуацій.

Кожна 3 інтегральних властивостей відображає умови, в рамках яких виникають процеси задоволення як біологічних, так і соціальних потреб членів суспільства. Послідовна ієрархічна декомпозиція кожного з них дозволяє «спуститися» до набору відповідних характеристик, які в переважній більшості можуть бути представлені стандартними статистичними показниками.

У Республіці Білорусь для вимірювання диспропорції у розвитку регіонів і столиці розроблено низку методик, що дозволяють кількісно оцінити ці диспропорції.

Регіональний інтегральний індекс якості життя населення дозволяє здійснити порівняння якості життя регіонів (областей) Республіки Білорусь. Індекс складається 338 статистичних показників, згрупованих у п'ять базових компонентів якості життя: якість населення; рівень життя населення; якість соціальної сфери; духовний та культурний стан суспільства; якість екосистеми. Причому для кожного з компонентів розраховується свій інтегральний індикатор, який за допомогою адитивної згортки перетворюється в єдиний узагальнений індикатор. Для відображення рівня життя білорусів розробники не використовують індикатор ВВП, замінюючи його показниками реальних доходів, витрат населення й забезпеченості 
житлом та іншою власністю. При побудові підсумкового показника врахований екологічний показник, характерний тільки для регіонів Білорусі, - радіоактивне забруднення території. Перевага методики полягає в тому, що всі показники, які використовуються, адаптовані до наявної статистичної бази у країні та зіставні в динаміці. У методиці також врахована нерівнозначність вихідних індикаторів і компонентів.

Аналіз національних підходів у різних країнах світу засвідчив достатню гнучкість i пристосованість більшості методик до особливостей розвитку тієї чи іншої країни. Низка методик передбачає можливість вимірювання якості життя на регіональному рівні. Водночас напрями, за якими здійснюється аналіз, більшою чи меншою мірою універсалізовані й наближені до міжнародних систем оцінок. Це дозволяє залучати до оцінки між- народний контекст і хоча 6 частково здійснювати міжкраїнові порівняння.

\section{3. Досвід вимірювання окремих компонентів якості життя населення в Україні}

Крім методик, які оцінюють якість життя безпосередньо через систему розроблених індикаторів, слід відзначити ще кілька індексів, що спрямовані на вивчення окремих сторін життя людини і суспільства (таблиця 2.3).

Індекс людського розвитку ПРООН (ІЛР) розраховується щорічно для 187 країн світу. Індекс визначається експертами ООН спільно з групою незалежних міжнародних дослідників, які використовують, поряд 3 аналітичними розробками, статистичні дані різних міжнародних організацій. Індекс публікується у спеціальній серії доповідей ООН про людський розвиток.

Таблиця 2.3 - Загальна характеристика індексів якості життя окремих країн

\begin{tabular}{|c|c|c|c|c|}
\hline Назва & $\begin{array}{c}\text { Суб'єкт, } \\
\text { який здійснює } \\
\text { розрахунок }\end{array}$ & $\begin{array}{l}\text { Принцип } \\
\text { розрахунку }\end{array}$ & Індикатори & $\begin{array}{c}\text { Кількість } \\
\text { охоплених } \\
\text { країн }\end{array}$ \\
\hline 1 & 2 & 3 & 4 & 5 \\
\hline $\begin{array}{l}\text { Індекс людсько- } \\
\text { го розвитку }\end{array}$ & ПРООН & $\begin{array}{l}\text { Середньо- } \\
\text { геометричне } \\
\text { трьох індексів }\end{array}$ & $\begin{array}{l}\text { Очікувана тривалість життя, освіта, } \\
\text { валовий національний дохід }\end{array}$ & 187 \\
\hline $\begin{array}{l}\text { Індекс добро- } \\
\text { буту (Prosperity } \\
\text { Index) [35] }\end{array}$ & $\begin{array}{l}\text { Дослідницька } \\
\text { організація } \\
\text { Legatum } \\
\text { Institute }\end{array}$ & $\begin{array}{l}\text { Інтегральна } \\
\text { оцінка пара- } \\
\text { метрів }\end{array}$ & $\begin{array}{l}\text { Економіка, рівень розвитку підпри- } \\
\text { ємництва і можливостей у бізнесі, } \\
\text { державне управління, освіта, охоро- } \\
\text { на здоров'я, рівень безпеки, особис- } \\
\text { та свобода, соціальний капітал }\end{array}$ & 110 \\
\hline $\begin{array}{l}\text { Індекс/рейтинг } \\
\text { міст } 3 \text { найви- } \\
\text { щою якістю } \\
\text { життя }\end{array}$ & $\begin{array}{l}\text { Консал- } \\
\text { тингова } \\
\text { компанія } \\
\text { Mercer Human } \\
\text { Resource } \\
\text { Consulting }\end{array}$ & $\begin{array}{l}\text { Рейтингові } \\
\text { оцінки }\end{array}$ & $\begin{array}{l}39 \text { критеріїв оцінювання: політико- } \\
\text { соціальне середовище, економічні } \\
\text { показники, наявність певних обме- } \\
\text { жень (наприклад, цензури), якість } \\
\text { системи охорони здоров'я, якість } \\
\text { системи освіти, доступність і вар- } \\
\text { тість житла, культурне життя, клімат і } \\
\text { ймовірність природних катаклізмів }\end{array}$ & $\begin{array}{l}215 \text { міст } \\
\text { світу }\end{array}$ \\
\hline $\begin{array}{l}\text { Індекс якості } \\
\text { життя Gallup } \\
\text { [37] }\end{array}$ & $\begin{array}{l}\text { Інститут } \\
\text { Gallup }\end{array}$ & $\begin{array}{l}\text { Соціологічне } \\
\text { обстеження } \\
\text { якості життя }\end{array}$ & $\begin{array}{l}\text { Здоров'я, освіта, матеріальний до- } \\
\text { статок, громадська активність, по- } \\
\text { літична свобода, соціальні зв'язки, } \\
\text { довкілля, економічна та фізична } \\
\text { безпека }\end{array}$ & $\begin{array}{l}\text { Зміню- } \\
\text { ється } 3 \\
\text { року в рік }\end{array}$ \\
\hline $\begin{array}{l}\text { Індекс людсько- } \\
\text { го розвитку } \\
\text { за методикою } \\
\text { Моніторингу } \\
\text { регіонального } \\
\text { людського } \\
\text { розвитку }\end{array}$ & $\begin{array}{l}\text { Інститут } \\
\text { демографії } \\
\text { та соціаль- } \\
\text { них дослід- } \\
\text { жень імені } \\
\text { М.В.Птухи }\end{array}$ & & Шість блоків, 33 показники & \\
\hline
\end{tabular}


ІЛР вимірює досягнення країни з позиції стану здоров'я, одержання освіти і фактичного доходу іï громадян за трьома основними напрямами, для яких розраховуються власні індекси: 1) Індекс валового національного доходу, вимірюваний величиною валового національного доходу на одну особу населення в доларах США за паритетами купівельної спроможності; 2) Індекс очікуваної тривалості життя: здоров'я та довголіття, вимірюваний показником середньої очікуваної тривалості життя при народженні; 3) Індекс освіти: доступ до освіти, що вимірюється середньою очікуваною тривалістю навчання дітей шкільного віку та середньою тривалістю навчання дорослого населення. Ці виміри стандартизуються у вигляді числових значень від 0 до 1, середнє геометричне яких являє собою інтегральний показник ІЛР (також зі значеннями від 0 до 1).

На основі аналізу досягнутого прогресу у сфері людського розвитку у 2010 р. експертами було запропоновано нові підходи до методики розрахунку людського розвитку, зокрема: побудову ІЛР з урахуванням масштабів нерівності, а також розрахунок індексу гендерної рівності та індексу багатовимірної бідності. У підсумковому рейтингу всі держави ранжуються на основі ІЛР і класифікуються на чотири категорії: 1) країни з дуже високим рівнем ІЛР; 2) країни з високим рівнем ІЛР; 3) країни із середнім рівнем ІЛР; 4) країни з низьким рівнем ІЛР.

Доповіді про людський розвиток ПРООН готуються на глобальному, регіональному, національному та суб-національному (локальному) рівнях. У підсумковому звіті зводяться всі основні показники «рівня життя» населення країн та регіонів, представлених у доповіді. При визначенні рейтингу враховуються такі чинники, як становище у сфері прав людини і громадянських свобод, можливість брати участь у суспільному житті, соціальна захищеність, ступінь територіальної та соціальної мобільності населення, показники рівня культурного розвитку населення, доступу до інформації, здоров'я, рівня безробіття, стану злочинності, охорони навколишнього середовища та ін.

Побудова рейтингів країн за ІЛР дозволяє оцінювати прогрес у реалізації стратегій і програм розвитку з метою забезпечення якісного життя населення та, відповідно, визначати напрями підвищення ефективності заходів державного впливу на людський розвиток.
Згідно з методологією Legatum Institute, який входить до міжнародної інвестиційної групи Legatum (відома британська дослідницька організація), розраховується Індекс добробуту (Prosperity Index) для 110 країн світу. Базою Індексу $\epsilon$ економетричний аналіз 89 показників, що відображають вплив різних чинників на добробут та дохід. Значущість впливу кожного показника визначається на основі регресійного аналізу або експертних оцінок, що дозволяє побудувати індекси нижнього порядку за такими 8 основними напрямами: економіка, рівень розвитку підприємництва і ведення бізнесу, державне управління, освіта, охорона здоров'я, рівень безпеки, особиста свобода, соціальний капітал [18].

Рейтинг міст з найвищою якістю життя складається щорічно міжнародною консалтинговою компанією у сфері людських ресурсів Mercer Human Resource Consulting. Список має важливе значення для компаній при прийнятті рішень, де вести свою діяльність і як оплачувати роботу своїх співробітників. Список ґрунтується на результатах щорічного порівняльного дослідження 215 міст світу. Оцінка проводиться на основі даних за 39 критеріями, такими як політико-соціальне середовище, економічні показники, наявність певних обмежень (наприклад, цензури), якість системи охорони здоров'я, якість системи освіти, доступність і вартість житла, культурне життя, клімат і ймовірність природних катаклізмів. За точку відліку зі 100 балами в рейтингу якості життя в містах було прийнято Нью-Йорк [19].

Методика Моніторингу регіонального людського розвитку України (розробники Інститут демографії та соціальних досліджень імені М. В. Птухи НАН України та Державна служба статистики України) розроблена у 2012 році й упроваджена в практику роботи органів державної статистики [20]. Методика спирається на ідеї та принципи, сформульовані ПРООН [21].

Виходячи з можливостей наявної інформаційної бази, національна методика передбачає більш повне урахування багатоаспектності людського розвитку, охоплюючи соціальне та природне середовище, фінансування відповідних напрямів соціально-економічної політики, безпосереднє віддзеркалення демографічної ситуації та розвитку ринку праці, більш де- 
тальну характеристику рівня життя, умов проживання, стану й охорони здоров'я населення.

Методика складається 3 шести блоків та загалом містить 33 показники. Попри суттєві новації система вимірювання регіонального людського розвитку залишається не повністю придатною для комплексного оцінювання якості життя в Україні. Вона ставить за кінцеву мету не стільки вимірювання якості життя, скільки обчислення блочних та інтегральних індексів, а також рейтингування регіонів за цими індексами. Оскільки переважна частина методики сконцентрована на статистикоматематичних перетвореннях індикаторів, фактичні значення показників відходять на другий план, вони сприймаються лише як матеріал для побудови індексних агрегатів.

Аналіз існуючих підходів до організації моніторингу компонентів якості життя населення України свідчить про необхідність розроблення спеціалізованої системи вимірювання, зорієнтованої на охоплення максимально широкого спектру проблем суспільного розвитку, комплексної і збалансованої з позиції відображення внеску кожного учасника політики якості життя - держави, суспільства, власне громадян.

Поняття «якість життя» використовується дуже широко, але воно не має загальновизнаної формалізованої структури і стандартного набору індикаторів. Пріоритети залежать від потреб людей, тісно пов'язані з рівнем соціально-економічного розвитку країн і регіонів, а також від можливості та джерел отримання достовірної інформації. Тому в різних міжнародних індексах використовуються різні критерії та різні методики розрахунку.

Узагальнення досвіду свідчить про наявність трьох ключових проблем, які необхідно розв'язати для забезпечення моніторингу оцінки якості життя в Україні:

$\checkmark$ розроблення концептуальних підходів до вимірювання якості життя;

$\checkmark$ формування системи показників;

$\checkmark$ визначення порядку розрахунку узагальнюючих показників. 


\section{3 КОНЦЕПТУАЛЬНІ ПІДХОДИ ДО роздп 3 ВИМІРЮВАННЯ ЯКОСТІ ЖИТТЯ В УКРАЇНІ}

\section{1. Загальний підхід}

Метою створення системи для оцінювання якості життя $є$ здійснення моніторингу якості життя для прийняття управлінських рішень на національному рівні. Специфіка вибору мети визначає вибір концептуальних основ побудови системи індикаторів. Це:

$\checkmark$ Національна адекватність має пріоритет над міжнародною порівнянністю. Система моніторингу і пропоновані індикатори повинні відповідати потребам України. Міжнародна порівнянність індикаторів бажана, але не обов'язкова.

$\checkmark$ Максимально широке охоплення всіх аспектів людського життя для оцінки якості життя. Для цілей моніторингу використовуватиметься принцип рівної значущості сфер людського життя.

$\checkmark$ Структуризація системи показників у вигляді певних блоків, які об'єднують низку показників, що оцінюють одну зі сфер людського життя.

$\checkmark$ Динамічний характер системи, що має забезпечувати можливість відстежувати зміну якості життя.

$\checkmark$ Перспективна спрямованість системи, яка повинна залишатися адекватною для оцінки якості життя у середньостроковій перспективі. Тому система показників має включати не лише існуючі розрахункові показники, але і цільові орієнтири.

$\checkmark$ Включення системи зворотного зв'язку таким чином, що самі громадяни стають користувачами системи. Це дасть змогу в процесі моніторингу отримувати інформацію безпосередньо від громадян, наприклад у визначенні того, які сфери якості життя самі громадяни вважають пріоритетними.

$\checkmark$ Наявність інтегрального індексу та набору субіндексів відповідно до структури системи показників - зважаючи на комплексність поняття «якість життя» та структуризацію системи показників.

«Якість життя» $є$ комплексним поняттям, яке повинне враховувати різноманітні аспекти людського життя. 3 погляду оцінювання якість життя $\epsilon$ багатовимірною величиною. Тому, з метою забезпечення адекватної оцінки їі слід будувати на основі національної матриці індикаторів, макси- мально адаптованої до державної статистики. При цьому вона може включати показники, які наразі не розраховуються, але потенційно така можливість існує. Також ця матриця по можливості (за окремими показниками) повинна забезпечити міжнародні порівняння.

Кожен індикатор може бути розглянутий 3 двох боків:

$\checkmark$ за джерелом отримання (об'єктивний суб'єктивний);

$\checkmark$ як характеристика певного середовища життєдіяльності.

Зусилля для забезпечення відповідного рівня якості життя населення (чи конкретної особи) здійснюються за двома напрямами: по-перше, це діяльність держави для забезпечення гідного рівня якості життя населення і, по-друге, це зусилля самих громадян. При цьому поділ на два зазначені джерела забезпечення якості життя $\epsilon$ доволі умовним. 3 одного боку, діяльність держави обмежується можливостями (у першу чергу фінансовими), що зумовлені і станом економіки, і певним станом населення, характеристиками якого в цьому сенсі $є$ статево-вікова структура (співвідношення населення працездатного та непрацездатного віку), поведінка на ринку праці (економічна активність, нелегальна зайнятість) тощо. 3 іншого боку, суспільно-економічна активність населення значною мірою зумовлена тими «правилами гри», за якими пропонує «грати» держава. У будь-якому разі якість життя забезпечується цими двома складовими: державою та населенням. При цьому слід брати до уваги, що ефективність зусиль держави менша, ніж самого населення: економічне зростання, збільшення фінансування певних програм не завжди $\epsilon$ ефективним та приводить до зростання якості життя; водночас зростання доходів населення практично завжди трансформується у підвищення якості життя. Крім того, у кожної особи $\epsilon$ власне уявлення про якість життя і можливості іï забезпечення у конкретних умовах існування. В основному це уявлення й зумовлює поведінку людини щодо підвищення якості свого життя.

Саме тому при розробці національної матриці індикаторів (системи показників) якості життя доцільно виокремити три блоки показників. 
Показники першого блоку повинні кількісно описувати зовнішнє середовище, характеризувати досягнутий стан, в якому відбувається життя людини і здійснюється оцінка якості життя.

Показники другого блоку мають забезпечити характеристику поточного стану якості життя. При цьому слід враховувати, що поточний стан формується як результат спільного впливу держави та населення.

Третій блок показників повинен відбивати суб'єктивну оцінку стану якості життя самим населенням. Суб'єктивна оцінка характеризує якість життя в окремих сферах з погляду індивідуума, тобто як він сприймає доступність різних ресурсів, а також можливість їх використання.

Високого рівня якості життя можна досягти лише при оптимальному балансі компонентів усіх трьох указаних блоків (стан, поточна ситуація і самооцінка). У цьому випадку доступність чинників якості життя може трансформуватись у високу статусність та високу самооцінку досягнутого статусу. Можливі дисбаланси у трьох компонентах вказують на проблеми з досягненням високої якості життя. Поєднання об'єктивних і суб'єктивних оцінок може дати чотири можливі варіанти розвитку подій - благополуччя, адаптацію, дисонанс і відторгнення (табл. 3.1).

Благополуччя $\epsilon$ результатом збігу позитивної оцінки об'єктивної та суб'єктивної картини. У разі негативних оцінок створюється ситуація відторгнення. Іншим поширеним випадком $\epsilon$ ситуація адаптації, коли об'єктивно погані умови сприймаються суб'єктивно як добрі, тобто індивідуум адаптується до умов («щасливі бідні люди»). У протилежній ситуації - об'єктивно добра ситуація суб'єктивно сприймається як погана - виникає дисонанс, тобто невідповідність очікуваної та отриманої якості життя, що може у подальшому призвести до політичних наслідків.
Важливим компонентом системи якості життя виступає конфігурація середовища та умови, за яких реалізуються цінності особистості, формується людський та соціальний капітал. Середовище якості життя формує можливості розвитку, які надаються людині, а також визначає ступінь відповідності умов життєдіяльності фізіологічним та психологічним потребам і цінностям людини. Діапазон таких можливостей включає різноманітні побутові, соціально-комунікативні, освітньо-просвітницькі, культурно-дозвільні та інші можливості членів суспільства.

Характеристики середовища життя диференціюються залежно від сфер людської життєдіяльності. На цій основі можна виділити: природне, соціальне, економічне та суспільнополітичне середовища. Відповідно до специфіки визначального впливу кожного з цих середовищ на якість життя, розрізняють такі підсистеми якості життя, як якість громадського, трудового, сімейного та особистого (індивідуально-дозвільного) життя (рис. 3.1).

Найважливішу роль у формуванні високих стандартів якості життя населення відіграє економічне середовище. Забезпечити високу якість життя без стабільного економічного розвитку, збалансованості видатків та доходів державного бюджету неможливо. В умовах цивілізаційних змін посилення уваги до проблематики якості життя стало результатом природної еволюції системи пріоритетів суспільного розвитку.

Європейський досвід свідчить, що навіть невисокий рівень стартових соціально-економічних умов дає змогу досягти суттєвого прогресу у забезпеченні високих соціальних стандартів у короткі строки. Люди протягом життя одного покоління відчули суттєве покращання власного добробуту, що цілком закономірно привело до розширення спектру потреб. Зокрема, нові вимоги почали висувати до сфери трудової діяльності: безпечність, інтерес, зручність

\section{Таблиця 3.1 - Матриця стану якості життя населення}

\begin{tabular}{c|c|l|}
\hline \multirow{2}{*}{$\begin{array}{c}\text { Суб'єктивна } \\
\text { оцінка }\end{array}$} & \multicolumn{1}{|c|}{ Об'єктивна ситуація } \\
\cline { 2 - 3 } Добре & \multicolumn{1}{|c|}{ Добре } & \multicolumn{1}{|c|}{ Плагано } \\
\hline Погонолуччя & $\begin{array}{l}\text { Дисонанс } \\
\text { Невідповідність очікуваної та отриманої } \\
\text { якості життя }\end{array}$ & $\begin{array}{l}\text { Адаптація } \\
\text { Пристосування до існуючих умов } \\
\text { («щасливі бідні люди») }\end{array}$ \\
\hline
\end{tabular}




\section{Рис. 3.1 - Середовище та підсистеми якості життя населення}

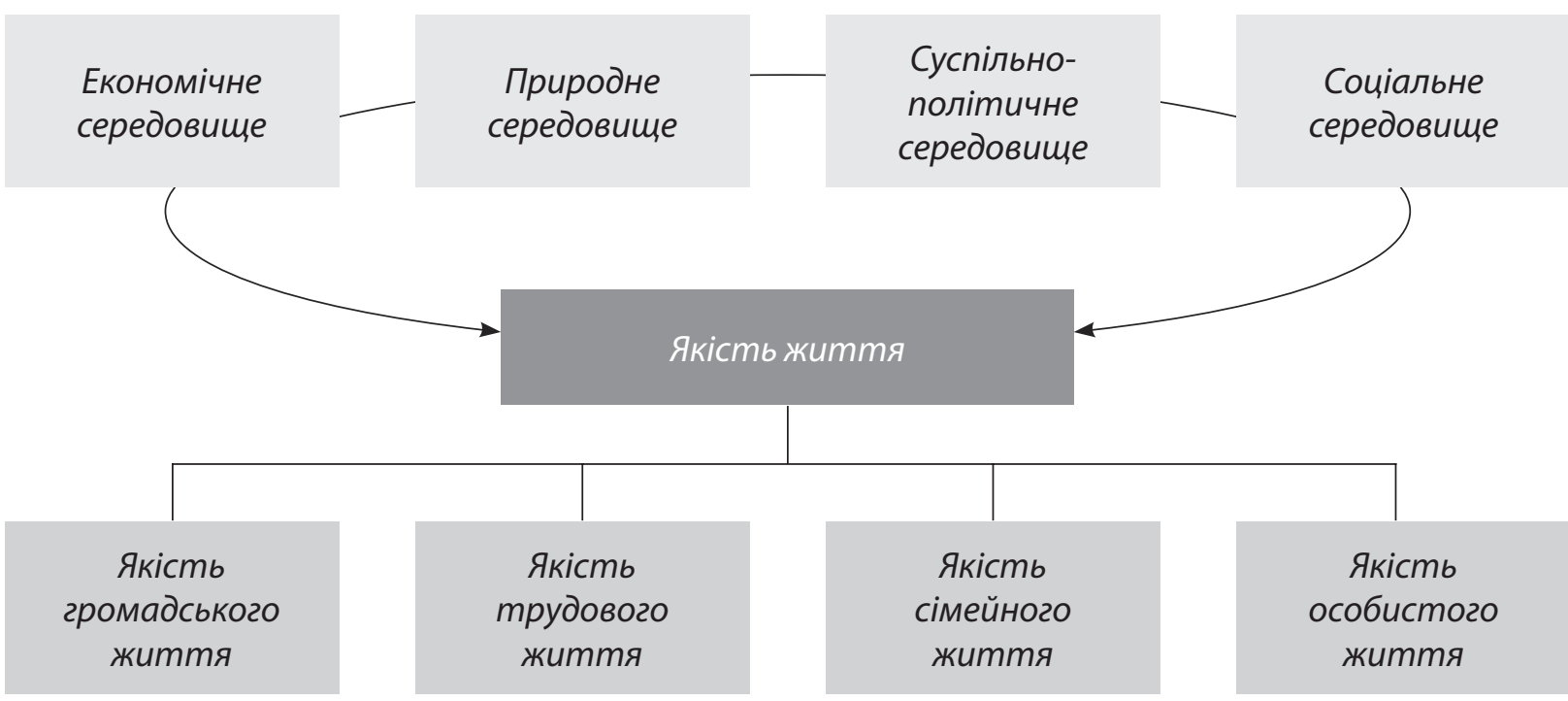

розташування, достатня кількість вільного часу; а у поняття «задоволеність життям» усе частіше включалися такі характеристики, як доступність та якість соціальних послуг освіти та охорони здоров'я [22].

Однак необхідною умовою забезпечення цього було підвищення рівня життя населення, що базувалося на розвитку високотехнологічної виробничої бази, стимулюванні внутрішнього споживчого попиту, виробництві конкурентоспроможної продукції зі значним вмістом добавленої вартості. У цьому контексті високотехнологічна виробнича база стає основним важелем підвищення стандартів якості життя.

Продуктивна зайнятість $\epsilon$ передумовою стійкого позитивного ефекту у сфері покращення якості життя. I навпаки, негативним чином на характеристики останньої впливає зростання безробіття, збільшення сегменту нестійкої зайнятості. Саме тому комплексне розв'язання макроекономічних проблем, забезпечення економічно активного населення ефективними робочими місцями, досягнення на цій основі високих результатів економічного розвитку та матеріального добробуту громадян - найважливіші передумови підвищення якості життя населення.

Не менш важливу роль у забезпеченні високої якості життя населення відіграє природне середовище. Будучи важливим фактором впливу на параметри якості життя, воно $є$ сукупністю умов проживання і виробничої діяльності людей. Природне середовище $\epsilon$ тією частиною навколишнього світу, з якою людина взаємодіє або шляхом пристосування, або шляхом пере- творення і використання. При цьому кінцевий результат діяльності людини в результаті застосування технологічних нововведень, з одного боку, та нераціонального використання природних ресурсів, з іншого, суттєво впливає на стан природного середовища. Значні обсяги забруднення навколишнього середовища виступають однією з основних причин погіршення здоров'я населення. Водночас потенціал навколишнього середовища (його спроможність приймати, переробляти і знешкоджувати відходи виробництва й споживання без негативних наслідків для нього самого) зменшується із року в рік із загрозливими темпами, що не може не впливати на якість життя населення усіх країн світу.

Прогресуюче забруднення навколишнього природного середовища висуває нові вимоги до системи пріоритетів економічного зростання, змушує суспільства замислитися про майбутнє людської цивілізації та місце у ньому. Загалом під якістю навколишнього природного середовища необхідно розуміти його здатність виконувати у довгостроковій перспективі функції середовища проживання і життєдіяльності людини, а також джерела збереження генофонду i біологічного різноманіття. Передумовою збереження та гармонізації природного середовища $\epsilon$ ефективна екологічна політика, без чого неможливе покращання якості життя населення.

Важлива роль у розробці та реалізації пріоритетів економічного зростання та природокористування належить розвитку громадянського суспільства. Репрезентуючи інтереси різних прошарків населення, громадянське суспільство $є$ гармонічною складовою 
суспільно-політичного середовища. При цьому, аналізуючи проблеми впливу останнього на якість життя, варто зазначити, що сильна соціальна політика, високий рівень видатків на освіту та охорону здоров'я створюють передумови, необхідні для соціальної стабільності. 3 іншого боку, вкрай важливою у контексті забезпечення якості життя $\epsilon$ можливість вільного висловлювання людиною власних політичних уподобань, своєї громадянської позиції.

Великою мірою параметри якості життя населення визначаються характером взаємодії особистості з оточуючим соціальним середовищем. Тому в процесі розробки заходів, спрямованих на покращення якості життя, важливо визначити сутність соціального середовища, а також закономірності та фактори його формування.
Варто зауважити, що тут під поняттям «соціальне середовище» мається на увазі переважно соціальна інфраструктура: система освіти та професійної підготовки, система охорони здоров'я, громадський транспорт, сфера культури, безпека проживання, умови проживання.

Таким чином, при формуванні національної матриці індикаторів якості життя доцільно виділити три блоки (стан, поточна ситуація, суб'єктивна оцінка) та чотири середовища (природне, соціальне, економічне, суспільно-політичне). При цьому останні три середовища мають свої субсередовища. Таким чином, матриця має тридцять три структурних елементи. Блоки, середовища (субсередовища) та їх структурні елементи наведені у табл. 3.2. При цьому кожний структурний елемент складається з низки показників.

\section{Таблиця 3.2 - Національна матриця індикаторів якості життя населення в Україні}

\begin{tabular}{|c|c|c|c|}
\hline \multicolumn{4}{|c|}{ Якість життя } \\
\hline \multirow{3}{*}{$\begin{array}{c}\text { Середовища } \\
\text { (субсередовища) }\end{array}$} & \multicolumn{3}{|c|}{ Блоки } \\
\hline & \multicolumn{2}{|c|}{ Об'єктивна оцінка } & \multirow{2}{*}{$\begin{array}{l}\text { Суб'єктивна } \\
\text { оцінка }\end{array}$} \\
\hline & Стан & Поточна ситуація & \\
\hline \multicolumn{4}{|c|}{ Природне середовище } \\
\hline Екологія & Природне середовище & Екологічна ситуація & $\begin{array}{l}\text { Оцінка екологічної } \\
\text { ситуації }\end{array}$ \\
\hline \multicolumn{4}{|c|}{ Соціальне середовище } \\
\hline Здоров'я & $\begin{array}{l}\text { Система охорони } \\
\text { здоров'я }\end{array}$ & Здоров'я населення & $\begin{array}{l}\text { Оцінка системи охорони } \\
\text { здоров'я та власного } \\
\text { здоров'я }\end{array}$ \\
\hline Освіта & Система освіти & Освіта населення & $\begin{array}{l}\text { Оцінка системи освіти та } \\
\text { власної освіти }\end{array}$ \\
\hline Безпека & $\begin{array}{l}\text { Криміногенне } \\
\text { середовище }\end{array}$ & Криміногенна ситуація & $\begin{array}{l}\text { Оцінка особистої } \\
\text { безпеки }\end{array}$ \\
\hline $\begin{array}{l}\text { Культура, } \\
\text { мистецтво, } \\
\text { відпочинок }\end{array}$ & $\begin{array}{l}\text { Сфера культури, } \\
\text { мистецтва, туризму }\end{array}$ & $\begin{array}{l}\text { Активність населення } \\
\text { у сфері культури, } \\
\text { мистецтва, туризму }\end{array}$ & $\begin{array}{l}\text { Ставлення до культури, } \\
\text { мистецтва, туризму }\end{array}$ \\
\hline Житло & Ринок житла & Житлові умови & $\begin{array}{l}\text { Оцінка благоустрою та } \\
\text { умов проживання }\end{array}$ \\
\hline Транспорт & $\begin{array}{l}\text { Транспортна } \\
\text { інфраструктура }\end{array}$ & Безпека на транспорті & $\begin{array}{l}\text { Оцінка роботи } \\
\text { транспорту }\end{array}$ \\
\hline \multicolumn{4}{|c|}{ Економічне середовище } \\
\hline Економіка & Стан економіки & Добробут & $\begin{array}{l}\text { Оцінка матеріального } \\
\text { становища }\end{array}$ \\
\hline Зайнятість & Ринок праці & $\begin{array}{l}\text { Зайнятість та умови } \\
\text { праці }\end{array}$ & $\begin{array}{l}\text { Оцінка ситуації щодо } \\
\text { зайнятості }\end{array}$ \\
\hline \multicolumn{4}{|c|}{ Суспільно-політичне середовище } \\
\hline $\begin{array}{l}\text { Громадянська } \\
\text { активність }\end{array}$ & $\begin{array}{l}\text { Розвиток громадянсько- } \\
\text { го суспільства }\end{array}$ & $\begin{array}{l}\text { Суспільно-політична } \\
\text { ситуація }\end{array}$ & $\begin{array}{l}\text { Оцінка суспільно- } \\
\text { політичної ситуації }\end{array}$ \\
\hline $\begin{array}{l}\text { Суспільне } \\
\text { середовище }\end{array}$ & $\begin{array}{l}\text { Стан суспільного } \\
\text { середовища }\end{array}$ & Соціальне уособлення & Соціальне самопочуття \\
\hline
\end{tabular}




\begin{tabular}{c|c|c|}
\hline Середовище: & Субсередовище: & Поточна ситуація: \\
\hline Соціальне & Здоров'я & Здоров'я населення
\end{tabular}

Індикатори:

Очікувана тривалість життя при народженні, обидві статі, років.

Захворюваність на ВІЛ, на 100 тис. населення.

Смертність від СНІДу, на 100 тис. населення.

Смертність від СНІДу, на 100 тис. населення (за європейським стандартом вікової структури).

Смертність від туберкульозу, на 100 тис. населення.

Смертність від туберкульозу, на 100 тис. населення (за європейським стандартом вікової

структури).

Рівень смертності, якій можна запобігти (показник керованої смертності), за окремим

мінімальним переліком причин, на 100 тис. населення.

Рівень передчасної смертності (0-64р.), на 100 тис. населення.

Ймовірність померти у віці від 15 до 60 років.

Частка осіб віком 18 років і старше, які займаються фізичною активністю не менше

30 хвилин 5 разів на тиждень, \%

Частка осіб віком 15 років і старше, які курять щоденно, \%

Коефіцієнт смертності дітей віком 0-4 роки.

Частка населення, яке має збалансований раціон харчування (за поживними речовинами та мікро- і макроелементами), \%.

Кількість хворих із уперше встановленим діагнозом алкоголізму і алкогольних психозів, розладу психіки та поведінки внаслідок вживання наркотиків та інших психоактивних речовин, на 100 тис. населення.

Частка домогосподарств, які за потреби не змогли відвідати лікаря.

Частка витрат на лікування у загальному бюджеті домогосподарств, \%.

Кількість випадків самогубств, на 100 тис. населення

\section{Середовище:}

Сочіальне

\section{Субсередовище:}

Здоров'я
Суб'єктивна оцінка:

Очінка системи охорони здоров'я та власного здоров'я

Індикатори:

Частка населення, яке оцінює свій стан здоров'я як «добрий» та «відмінний», \%.

Частка населення, якому вистачає необхідної медичної допомоги, \%.

Оцінка задоволеності нинішнім станом системи охорони здоров'я.

Частка населення, яке не відчуває труднощів або обмежень у повсякденному житті внаслідок хронічних захворювань, інвалідності, фізичної слабкості чи проблем з психікою, \%.

Середня очікувана тривалість здорового життя, років.

\section{Середовище:}

Сочіальне

\section{Субсередовище:}

Освіта
Стан:

Система освіти

Індикатори:

Бюджетні видатки на освіту, у \% до ВВП.

Співвідношення загальних (сумарних) видатків бюджетів усіх рівнів на освіту 3 визначеними за соціальними стандартами, \%.

Забезпеченість учнів денних загальноосвітніх навчальних закладів обчислювальною технікою, одиниць на 10 тис. учнів.

Забезпеченість студентів денної форми навчання вищих навчальних закладів обчислювальною технікою, одиниць на 10 тис. студентів.

Частка денних загальноосвітніх навчальних закладів, що мають доступ до Інтернету, \%. 


\section{Середовище: \\ Субсередовище: \\ Поточна ситуація: \\ Сочіальне \\ Освіma \\ Освіта населення}

Індикатори:

Чистий показник охоплення дошкільними навчальними закладами дітей віком 3-5 років, \%.

Охоплення загальною середньою освітою дітей шкільного віку, \%.

Частка осіб із вищою освітою серед населення віком 25 років і старше, \%.

Середня тривалість навчання осіб віком 25 років і старше, років.

Частка витрат на освіту у загальному бюджеті домогосподарств, \%.

\begin{tabular}{|c|c|c|}
\hline Середовище: & Субсередовище: & Суб'єктивна оцінка: \\
\hline Соціальне & Освіта & Оцінка системи освіти та \\
власної освіти
\end{tabular}

Індикатори:

Частка населення, яке скоріше або повністю задоволено своєю освітою, \%.

Частка населення, якому не вистачає можливості дати дітям повноцінну (бажану) освіту, \%.

Оцінка нинішнього стану системи освіти.

\begin{tabular}{|c|c|c|}
\hline Середовище: & Субсередовище: & Стан: \\
\hline Соціальне & Безпека & Криміногенне середовище \\
\hline
\end{tabular}

Індикатори:

Кількість засуджених, які відбувають покарання, на 100 тис. населення.

Кількість засуджених, які відбули покарання (вийшли на волю) за попередні 25 років, на 100 тис. населення.

Кількість організованих злочинних угруповань, одиниць

\begin{tabular}{|c|c|c|}
\hline Середовище: & Субсередовище: & Поточна ситуація: \\
\hline Соціальне & Безпека & Криміногенна ситуація \\
\hline
\end{tabular}

Індикатори:

Коефіцієнт злочинності, кількість зареєстрованих злочинів на 100 тис. населення.

Коефіцієнт вбивств, кількість зареєстрованих вбивств на 100 тис. населення.

Питома вага молоді віком до 30 років, засудженої до позбавлення волі, \%.

Частка рецидивних (повторних) злочинів, \%.

\begin{tabular}{|c|c|c|}
\hline Середовище: & Субсередовище: & Суб'єктивна оцінка: \\
\hline Соціальне & Безпека & Особиста безпека \\
\hline
\end{tabular}

Індикатори:

Частка населення, яке вважає, що біля їх будинку / в мікрорайоні практично не трапляються випадки хуліганства та пограбувань, \%.

Частка населення, яке почуває себе безпечно у районі свого проживання з настанням темряви, \%.

Частка населення, яке вважає, що протягом останніх 12 місяців значно погіршилася особиста безпека (на вулиці, в громадських місцях), \%.

Частка населення, яке ставало жертвами пограбування або фізичного насильства за останні п'ять років, \%.

Частка населення, яке незадоволено роботою міліції, \%. 


\section{Середовище:}

Сочіальне
Субсередовище:

Культура, мистецтво, відпочинок
Стан:

Сфера культури, мистецтва, туризму

\section{Індикатори:}

Бюджетні видатки на культуру, мистецтво, фізичну культуру, туризм, у \% до ВВП.

Співвідношення загальних (сумарних) видатків бюджетів усіх рівнів на культуру, мистецтво, фізичну культуру із визначеними за соціальними стандартами, \%.

Кількість закладів культури, мистецтва за видами (театри, музеї, бібліотеки, стадіони, палаци спорту, гуртки тощо), на 100 тис. населення.

Частка закладів культури, що потребують капітального ремонту, \%.

\section{Середовище: \\ Сочіальне}

Поточна ситуація:

Активність населення у сфері культури, мистецтва, туризму

\section{Індикатори:}

Кількість внутрішніх туристів і екскурсантів, на 100 тис. населення.

Частка населення, яке хоча б один раз було за кордоном з туристичною метою, \% Відвідуваність населенням (як глядачі) закладів культури, мистецтва за видами (театри, музеї, бібліотеки, стадіони, палаци спорту, гуртки тощо), на 100 тис. населення.

Відвідуваність населенням (як учасники гуртків, секцій тощо) закладів культури, мистецтва за видами, на 100 тис. населення.

Частка населення, яке хоча б один раз відвідало інший регіон України з туристичною метою, \%.

Частка населення, яке користується Інтернетом (вдома, на роботі чи в інших місцях), \%. Співвідношення витрат часу на роботу та відпочинок.

\section{Середовище:}

Сочіальне

\section{Субсередовище:}

Культура, мистецтво, відпочинок
Суб'єктивна оцінка:

Ставлення до культури, мистецтва, туризму

\section{Індикатори:}

Частка населення, якому вистачає повноцінного дозвілля, \%.

Частка населення, якому вистачає можливості повноцінно проводити відпустку, \%.

Частка населення, у якого покращилася можливість брати участь у культурному житті (театри, музеї, бібліотеки, стадіони, палаци спорту, гуртки тощо) протягом останнього року, \%. Частка населення, у якого немає потреби відвідувати заклади культури, мистецтва, фізичної культури, \%.

\begin{tabular}{|c|c|c|}
\hline Середовище: & Субсередовище: & Стан: \\
\hline Сочіальне & Житло & Ринокжитла \\
\hline
\end{tabular}

Індикатори:

Середня вартість загальної площі введених в експлуатацію нових житлових будинків, тис. грн / кв. м.

Середня вартість оренди житла у столиці, євро / кв. м. за місяць.

Кількість сімей та одинаків, які проживають у житлі, що не відповідає санітарним нормам, на 100 тис. населення.

Кількість сімей та одинаків, які потребують отримання соціального житла, на 100 тис. населення. 


\section{Середовище: \\ Субсередовище: \\ Поточна ситуація: \\ Сочіальне \\ Житло \\ Житлові умови}

Індикатори:

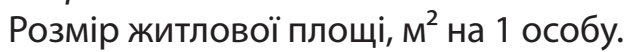

Частка домогосподарств, які мешкають у житлі, що обладнане базовими зручностями, \%.

Частка населення, яке мешкає в житлі, що відповідає сучасним стандартам, \%.

Частка домогосподарств, які беруть питну воду з мережі водопостачання, \%.

\begin{tabular}{c|c|c|}
\hline Середовище: & Субсередовище: & Суб'єктивна оцінка: \\
\hline Соціальне & Житло & Оцінка благоустрою та умов \\
проживання
\end{tabular}

Індикатори:

Частка населення, яке повністю (скоріше за все) задоволене проживанням у своєму населеному пункті, \%.

Частка населення, яке задоволене благоустроєм та санітарним станом вулиць, парків, довкілля (за місцем проживання), \%.

Частка населення, яке повністю задоволене кількісними та якісними характеристиками свого житла, \%.

\begin{tabular}{|c|c|c|}
\hline Середовище: & Субсередовище: & Стан: \\
\hline Сочіальне & Транспорт & Транспортна інфраструктура \\
\hline
\end{tabular}

Індикатори:

Розгалуженість транспортної інфраструктури (інтенсивність сполучення сіл з районними центрами та районних - з обласними).

Частка доріг, які потребують капітального ремонту (за категоріями доріг), \%.

Частка парку громадського транспорту, яка потребує заміни (за видами транспорту), \%.

\begin{tabular}{|c|c|c|}
\hline Середовище: & Субсередовище: & Поточна ситуація: \\
\hline Соціальне & Транспорm & Безпека на транспорті \\
\hline
\end{tabular}

Індикатори:

Кількість загиблих у ДТП, на 100 тис. населення.

Кількість загиблих у ДТП, на 100 тис. км доріг.

Кількість травмованих у ДТП, на 100 тис. населення.

Кількість ДТП, на 100 тис. населення.

\begin{tabular}{|c|c|c|}
\hline Середовище: & Субсередовище: & Суб'єктивна оцінка: \\
\hline Соціальне & Транспорm & Оцінка роботи транспорту \\
\hline
\end{tabular}

Індикатор:

Частка населення, яке задоволене роботою громадського транспорту, \%.

\begin{tabular}{c|c|c} 
Середовище: & Субсередовище: & Стан: \\
\hline Економічне & Економіка & Стан економіки
\end{tabular}

Індикатори:

ВВП на одну особу за ПКС у дол. США.

Індекс споживчих цін.

Індекс економічної свободи.

Співвідношення зовнішнього боргу та ВВП, \%.

Дефіцит Пенсійного фонду, \%.

Співвідношення дотацій і виплат та фонду заробітної плати, \%.

Рівень тінізації економіки, \%.

Вартість життя людини, тис. грн. 


\section{Середовище: \\ Субсередовище: \\ Поточна ситуація: \\ Економічне \\ Економіка \\ Добробут}

Індикатори:

Частка населення, яке має сукупні еквівалентні витрати менше $75 \%$ медіанного рівня

(відносний рівень бідності), \%.

Питома вага витрат на харчування в сукупних витратах домогосподарств, \%.

Частка осіб, харчування яких відповідає санітарним нормам, \%.

Частка осіб, які не могли дозволити собі протягом останніх 12 місяців відпочинок поза домом, \%.

Частка осіб, які не могли дозволити собі протягом останніх 12 місяців купити книги, білети до театру, кіно, \%.

Співвідношення доходів 20\% найбільш та 20\% найменш заможного населення, разів.

Співвідношення витрат часу на домашню роботу та відпочинок, разів.

Частка неофіційних доходів у загальних доходах громадян, \%.

\section{Середовище:}

Економічне

\section{Субсередовище:}

Економіка
Суб'єктивна оцінка:

Очінка матеріального становища

\section{Індикатори:}

Частка населення, яке вважає себе бідними, \%.

Частка населення, яке визначає свої доходи як такі, що забезпечують, крім харчування, задоволення інших потреб, \%.

Частка населення, яке позитивно сприймає зміни свого матеріального становища протягом останніх 12 місяців, \%.

Частка населення, яке живе комфортно та може жити на свій дохід.

\section{Середовище: \\ Економічне}

\section{Субсередовище:} Зайнятість

\section{Стан:}

Ринок праці

\section{Індикатори:}

Рівень безробіття серед населення віком 20-65 років за методологією МОП, \%.

Частка працюючих за наймом у загальній чисельності зайнятого населення, \%.

Рівень тривалого безробіття (більше 12 місяців) за методологією МОП, \%.

Частка осіб, працевлаштованих за кордоном за допомогою офіційних посередників, у

загальній чисельності населення віком 18-65 років, \%.

Частка іноземців, які працюють в Україні, в загальній чисельності зайнятого населення, \%.

Частка професіоналів та фахівців серед зайнятого населення, \%.

\section{Середовище: \\ Субсередовище: \\ Поточна ситуація: \\ Економічне \\ Зайнятість \\ Зайнятість та умови прачі}

Індикатори:

Рівень зайнятості населення (частка зайнятих серед населення віком 20-65 років), \%.

Економічна активність населення віком 20-65 років, \%.

Частка працівників, які працюють в умовах, що не відповідають санітарно-гігієнічним нормам, \%.

Рівень охоплення соціальним страхуванням (частка застрахованих осіб у зайнятому населенні), \%.

Час, який щоденно витрачається для поїздок на роботу та у зворотному напрямі, годин. 


\begin{tabular}{c|c|c|}
\hline Середовище: & Субсередовище: & Суб'єктивна оцінка: \\
\hline Економічне & Зайнятість & Очінка ситуації щодо зайнятості
\end{tabular}

Індикатори:

Частка населення, яке вважає, що у населеному пункті легко можна знайти роботу 3 задовільною оплатою праці та відповідної кваліфікації, \%.

Частка населення, яке вважає, що у населеному пункті легко можна знайти роботу з задовільною оплатою праці, але без відповідної кваліфікації, \%.

Частка населення, яке не задоволене роботою, \%.

Частка працюючих респондентів, які вважають, що гарантовано пропрацюють на своїй роботі ще, як мінімум, протягом одного року, \%.

\section{Середовище: \\ Субсередовище: \\ Стан:}

Суспільно-політичне
Громадянська активність
Розвиток громадянського суспільства

\section{Індикатори:}

Індекс сталості розвитку організацій громадянського суспільства.

Індекс свободи.

Індекс демократії.

Кількість політичних, релігійних та громадських організацій (профспілки, творчі спілки, ОСББ, клуби за інтересами тощо), на 100 тис. населення.

\section{Середовище: \\ Субсередовище: \\ Поточна ситуація: \\ Суспільно-політичне Громадянська активність \\ Суспільно-політична ситуація}

Індикатори:

Кількість громадян, які беруть участь у роботі політичних, релігійних та громадських організацій (профспілки, творчі спілки, ОСББ, клуби за інтересами тощо), на 100 тис. населення віком 16 років і старше.

Кількість волонтерів, на 100 тис. населення віком 16 років і старше.

Частка осіб, які притягалися до адміністративної відповідальності, на 100 тис. населення віком 16 років і старше.

\section{Середовище:}

Суспільно-політичне
Субсередовище:

Громадянська активність
Суб'єктивна оцінка:

Очінка суспільно-політичної cumyauii

\section{Індикатори:}

Частка населення, яке задоволене розвитком демократії, \%.

Частка населення, яке задоволене роботою уряду, \%.

Частка населення, яке вважає, що сьогодні в Україні люди можуть вільно висловлювати свої політичні погляди, \%.

Частка населення, яке переважно та цілком довіряє певним інститутам влади (Президенту, Верховній Раді, уряду тощо), \%.

Частка населення, яке оцінює в цілому політичну ситуацію в Україні як спокійну та благополучну, \%.

Частка населення, яке вважає, що може щось зробити проти рішення уряду країни, коли той утискає законні права та інтереси громадян, \%.

Індекс довіри до органів влади.

Індекс довіри до релігійних організацій.

Індекс довіри до 3МІ.

Частка населення, яке протягом останніх 12 місяців безрезультатно зверталося до місцевої адміністрації, \%.

Частка населення, яке скоріше задоволене роботою органів місцевої влади, \%. 


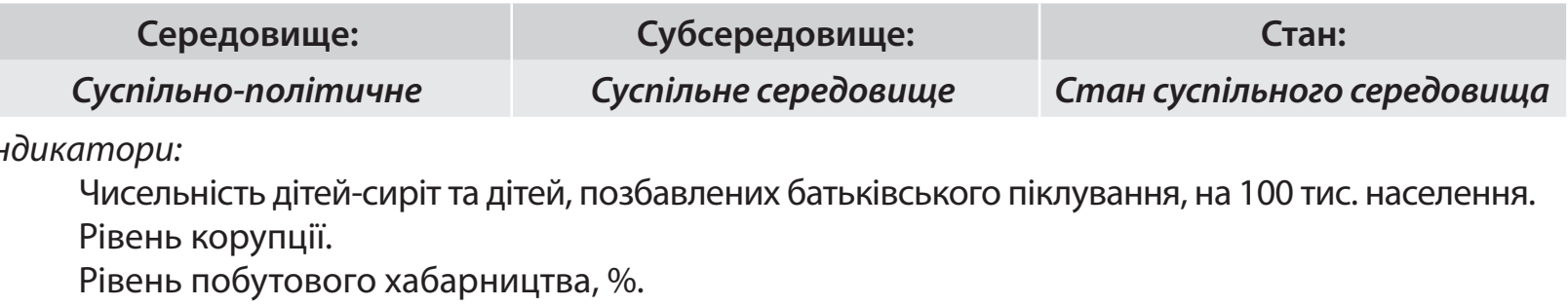

\begin{tabular}{|c|c|c|}
\hline Середовище: & Субсередовище: & Поточна ситуація: \\
\hline Суспільно-політичне & Суспільне середовище & Соціальне уособлення \\
\hline
\end{tabular}

Індикатори:

Сумарний коефіцієнт народжуваності, \%.

Загальний коефіцієнт розлучуваності, \%.

Частка домогосподарств, що складаються з однієї особи, \%.

Кількість усиновлених дітей-сиріт та дітей, позбавлених батьківського піклування, на 100 тис. їх чисельності

Частка дітей, народжених жінками, які не були у зареєстрованому шлюбі, \%.

\begin{tabular}{|c|c|c|}
\hline Середовище: & Субсередовище: & Суб'єктивна оцінка: \\
\hline Суспільно-політичне & Суспільне середовище & Соціальне самопочутmя \\
\hline
\end{tabular}

Індикатори:

Частка населення, яке повністю або скоріше за все задоволене своїм життям, \%.

Інтегральний індекс соціального самопочуття.

Частка населення, яке відчуває себе захищеним від свавілля влади, чиновників, \%.

Частка населення, яке задоволене своїм становищем у суспільстві, \%.

Частка населення, яке відчуває себе самотнім, \%.

Частка населення, якому немає до кого звернутися у випадку надзвичайної ситуації, коли необхідно еквівалент EUR500, \%.

Індекс довіри співвітчизникам.

Частка населення, яке взагалі нікому не довіряє, \%.

Інтегральний індекс національної дистанційованості.

Частка населення, яке не бере участі у роботі жодної політичної або громадської організації, \%.

\section{3. Розрахунок узагальнюючих показників}

Відповідно до концептуальних принципів вимірювання якості життя, викладених раніше, воно (вимірювання) повинно складатися з інтегрального індексу та набору субіндексів згідно зі структурою системи показників. Таким чином, загальна оцінка $\epsilon$ інтеграцією часткових оцінок. Тобто виникає питання щодо елементарного індексу, тобто індексу, який би, з одного боку, розраховувався на основі певного набору показників, а з іншого - слугував складовою розрахунку субіндексів та інтегрального індексу.

У нашому випадку ця проблема вирішується доволі просто - за елементарний індекс природно взяти індекс структурного елементу національної матриці індикаторів якості життя (див. табл. 3.2). При цьому з урахуванням однакової значущості блоків і середовищ слід дотримуватися таких положень.

1. Усі блоки (стан, поточна ситуація, суб'єктивна оцінка) рівноцінні.

2. Усі середовища та субсередовища рівноцінні.

Загальна процедура розрахунку поділяється на дві частини:

а) розрахунки індексів структурних елементів матриці;

б) розрахунки субіндексів та інтегрального індексу.

А) Послідовність розрахунку індексу структурного елементу матриці передбачає три етапи:

1) нормування показників;

2) визначення ваг показників;

3) розрахунок індексу. 
Нормування може здійснюватися за різними підходами [23], які можна умовно розподілити на три групи: 1) з урахуванням варіативності ознаки; 2) без урахування варіативності ознаки; 3) 3 використанням математичних функцій. До першої групи віднесені процедури нормування 3 використанням середньоквадратичного відхилення або розмаху варіації ознаки; до другої - з використанням нормативного значення ознаки, яким можуть виступати середнє значення ознаки, максимальне, мінімальне, медіанне або будь-яке інше, що може використовуватись як стандартне (еталонне) значення.

Третю групу складають способи нормування 3 використанням різних математичних функцій, таких як логарифмічна, гіперболічного тангенса тощо.

Застосування різних методів нормування призводить до результатів, що відрізняються. Крім того, окремі методи нормування змінюють форму розподілу ознаки, що, у свою чергу, змінює певні співвідношення між ознаками.

Таким чином, спосіб нормування впливає на подальшу обробку даних, у тому числі (як у нашому випадку) - і на значення елементарного індексу, субіндексів та інтегрального індексу. На цьому етапі питання вибору способу нормування не $є$ остаточно вирішеним як таке, що потребує певних поглиблених досліджень.

Ваги показників також впливають на значення індексу, їх визначення $\epsilon$ наступною проблемою. На нашу думку, ваги повинні визначатись експертами. Одним із методів, який може бути використаний і був апробований при розробці методики вимірювання регіонального людського розвитку, $є$ метод попарних порівнянь.

Для забезпечення зіставності результатів розрахунків за різні роки спосіб нормування та ваги показників повинні постійними протягом тривалого часу. Їх зміна потребуватиме проведення перерахунків усіх попередніх даних.

Індекс I структурного елементу матриці розраховується за формулою:

$$
I=\sum_{i=1}^{k} w_{i} z_{i}
$$

$z_{i}$ - нормоване значення і-го показника;

$w_{i}$ - вага і-го показника.

Б) Розрахунок субіндексів та інтегрального індексу.

На підставі індексів структурних елементів матриці, яких загалом налічується 33, розраховується інтегральний індекс і, залежно від мети, різні субіндекси. Останні можуть бути визначені за блоками, по середовищах (субсередовищах), за джерелами отримання (об'єктивне, суб'єктивне).

Відповідно до подальшої роботи 3 інтегральним індексом і субіндексами, вони можуть бути розраховані або як сумарні, або як середні показники. Сумарні показники дають змогу визначити внесок кожного індексу структурного елементу матриці в узагальнюючий індекс. Середні показники доцільно використовувати, коли кількості складових сукупностей, що порівнюються, відрізняються (наприклад, середовища мають різну кількість субсередовищ). 


\section{СПИСОК ВИКОРИСТАНИХ ДЖЕРЕЛ}

1. Walter Radermacher, Walter (Director General of Eurostat; Chief Statistician of the EU). Measuring prosperity and quality of life / Keynote Speech at the Austrian Federal Ministry of Finance in Vienna, May 2010 // http://epp.eurostat. ec.europa.eu/portal/ page/portal/gdp_and_ beyond/documents/wr_speach.pdf

2. Farquhar M. Quality of life in older people // Advances in Medical Sociology. - 1994. № 5. - C. 139-158

3. Айвазян С.А. Интегральные индикаторы качества жизни населения:ихпостроение и использование в социально-экономическом управлении и межрегиональных сопоставлениях. - М.: ЦЭМИ РАН, 2000. - 118 с.

4. Приступа $\in$., Кеуриш Н. Якість життя людини: категорії, компоненти та їх вимірювання // Фізична активність, здоров'я i спорт. - 2010. - № 2. - С. 54-63.

5. Агжанов Р.А. Социально-экономический мониторинг качества жизни населения городов // Вестник Удмуртского университета, 2006. - № 2. - С. 182-191

6. Istanbul Declaration on Human Settlements. UN-habitat. For a Better Urban Future [Електронний ресурс]. - Режим доступу: http://www.unhabitat.org/declarations/istdec.htm

7. Измерение прогресса в развитии обществ: Доклад Организации экономического сотрудничества и развития [Електронний ресурс]. - Режим доступу: http://www.unescap. org/stat/cst/1/CST1-8R.pdf

8. Istanbul OECD World Forum on Statistics, Knowledge and Policy / »Measuring and Fostering the Progress of Societies» [Електронний ресурс]. - Режим доступу: http://www.oecd.org/site/worldforum06/ istanbulworldforum-measuringandfosteringtheprogressofsocieties.htm

9. Beyond GDP:Measuring progress, true wealth, and the well-being of nations: European Commission, European Parliament, Club of Rome, WWF and OECD Conference. 19-20 November 2007 [Електронний ресурс]. Режим доступу: http://www.beyond-gdp.eu/ proceedings/bgdp_proceedings_full.pdf
10. Жеребин В.М. Индикаторы качества жизни населения // Вопросы статистики. - 2012. № 3. $-88 \mathrm{c}$.

11. BERENGER V., VERDIER-CHOUCHANE A. Multidimensional Measures of Well-Being: Standard of Living and Quality of Life Across Countries // World Development. - 2007. Vol. 35, No. 7. - pp. 1259-1276.

12. Офіційний сайт видання International Living [Електронний ресурс]. - Режим доступу: http://internationalliving.com/2010/12/ quality-of-life-2011/

13. Canadian Index of Wellbeing. Domains [Електронний ресурс]. - Режим доступу: https://uwaterloo.ca/canadian-index-wellbeing/our-products/domains

14. Нугаев Р.М., Нугаев М.А. Качество жизни в трудах социологов США // Социол. исслед. - 2003. - № 6. - С. 100-105.

15. Fahey T., Nolan B., Whelan C. 2003. Monitoring quality of life in Europe, European Foundation for the Improvement of Living and Working Conditions, Office for Official Publications of the European Communities, Luxembourg

16. How Are Canadians Really Doing: Canadian Index of Well-Being [Електронний peсурс]. - Режим доступу: http://ciw.ca/ reports/en/Reports\%20and\%20FAQs/CIWHowAreCanadiansReallyDoing-FINAL.pdf

17. Local quality of life indicators - supporting local communities to become sustainable. A guide to local monitoring to complement the indicators in the UK Government Sustainable Development Strategy / Audit Commission, ODPM and DEFRA [Електронний peсурс]. - Режим доступу: http://www.auditcommission.gov.uk/SiteCollectionDocuments /AuditCommissionReports/NationalStudies/ QofL2005.pdf

18. Second European Quality of Life Survey. Overview / European Foundation for the Improvement of Living and Working Conditions [Електронний ресурс]. - Режим доступу: http://www.eurofound.europa.eu/ pubdocs/ 2009/02/en/2/EF0902EN.pdf

19. Introducing the Revolting Index / The Wallstreet Journal [Електронний pe- 
сурс]. - Режим доступу: http://blogs.wsj. com/source/2011/02/25/introducing-therevolting-index/?mod=e2tw

20. Регіональний людський розвиток: Стат. бюл. / Відп. за випуск І.В.Калачова. - К. : Держстат України, 2012. - 45 с.

21. Независимый институт социальной политики, интегральные индексы [Электронный ресурс]. - Режим доступа: http://www. socpol. ru/atlas/indexes/index_life.shtml

22. Олсон М. Возвышение и упадок народов. Экономический рост. Стагфляция. Социальный склероз. - Новосибирск, 1998.

23. Гладун О.М. Лущик Л.В. Нормування як складова аналізу даних / Прикладна статис- тика: проблеми теорії та практики : 3бірник наукових праць. - К., Держкомстат України, Національна академія статистики обліку та аудиту. - 2010. - Вип. 6. - С. 36-46.

24. Звіт по науково-дослідній роботі «Розроблення системи індикаторів оцінки якості життя населення України для здійснення комплексного моніторингу, у тому числі порівняння $з$ іншими країнами» Інституту демографії та соціальних досліджень імені М.В. Птухи НАН України на замовлення Міністерства економічного розвитку та торгівлі України (№ державної реєстрації 0112U008469) // К.: Ін-т демографії та соц. досліджень імені М.В. Птухи НАН України, 2012. -670 c. 


\section{ДОДАТКИ}

нодаток $\mathrm{A}$

ПОКАЗНИКИ ОЦІНЮВАННЯ ЯКОСТІ ЖИТТЯ ЗА МЕТОДОЛОГІЕЮ ТНЕ ЕСОNОМІSТ

INTELLIGENCE UNIT

Таблиця А.1 - Методологія Economist Intelligence Unit: напрями та індикатори оцінювання якості життя

\begin{tabular}{|c|c|}
\hline Напрями якості життя & Індикатори якості життя \\
\hline Здоров'я & Очікувана тривалість життя при народженні \\
\hline Сімейне життя & $\begin{array}{l}\text { Поширеність розлучень (на } 1000 \text { осіб) - оцінка від } 1 \text { (найнижчий } \\
\text { рівень розлучень) до } 5 \text { (найвищий) }\end{array}$ \\
\hline Громадське життя & $\begin{array}{l}\text { Рівень відвідування богослужінь; членство у профспілках (набуває } \\
\text { значення 1, якщо країна має високі показники; нуль - в іншому } \\
\text { випадку) }\end{array}$ \\
\hline $\begin{array}{l}\text { Добробут за матеріальною } \\
\text { ознакою }\end{array}$ & $\begin{array}{l}\text { ВВП на одну особу населення } \\
\text { (за паритетом купівельної спроможності) }\end{array}$ \\
\hline Політична стабільність і безпека & Індекси політичної стабільності та безпеки \\
\hline Клімат та географія & Диференціація країн за ознакою теплого чи холодного клімату \\
\hline Гарантії зайнятості & Рівень безробіття, у\% \\
\hline Політична свобода & $\begin{array}{l}\text { Індекс політичної свободи - оцінка від } 1 \text { (найбільш позитивне } \\
\text { значення) до } 7 \text { (найбільш негативне значення) }\end{array}$ \\
\hline Гендерна рівність & $\begin{array}{l}\text { Співвідношення трудових доходів чоловіків та жінок } \\
\text { (у середньому) }\end{array}$ \\
\hline
\end{tabular}

Джерело: Economist Intelligence Unit [Електронний ресурс]. - Режим достуny: http://www.eiu.com/Default.aspx; http://www.economist.com/media/ pdf/QUALITY_OF_LIFE.pdf 


\section{ДОДАТОК $\mathbf{D}$ ПОКАЗНИКИ ОЦІНЮВАННЯ ЯКОСТІ ЖИТТЯ ЗА МЕТОДОЛОГІЕЮ ЄВРОСТАТУ (EUROPEAN STATISTICAL SYSTEM COMMITTEE)}

\section{Таблиця Б.1 - Методологія European Statistical System Committee - ESSC: напрями та індикатори}

\begin{tabular}{|c|c|c|}
\hline \multicolumn{2}{|c|}{ Напрями } & Індикатори \\
\hline \multicolumn{3}{|c|}{ Матеріально-побутові умови (Material living conditions) } \\
\hline \multirow{5}{*}{ Доходи (Income) } & & $\begin{array}{l}\text { Середні та медіанні доходи за віком і статтю } \\
\text { (Mean and median income by age and sex) }\end{array}$ \\
\hline & & $\begin{array}{l}\text { Ризик бідності за порогом бідності, віком та статтю (At- } \\
\text { risk-of-poverty rate by poverty threshold, age and sex) }\end{array}$ \\
\hline & & $\begin{array}{l}\text { Ризик бідності на певний момент часу ( } 2008 \text { рік) за ві- } \\
\text { ком та статтю (At-risk-of-poverty rate anchored at a fixed } \\
\text { moment in time (2008) by age and sex) }\end{array}$ \\
\hline & & $\begin{array}{l}\text { Співвідношення останнього та першого квінтилей за } \\
\text { статтю та віком (S80/S20 income quintile share ratio by sex } \\
\text { and selected age group) }\end{array}$ \\
\hline & & $\begin{array}{l}\text { Задоволеність фінансовим станом домогосподарства } \\
\text { (на стадії розробки в } 2013 \text { SILC) } \\
\text { (Satisfaction with financial situation of the } \\
\text { household (under development inSILC 2013)) }\end{array}$ \\
\hline \multirow{3}{*}{$\begin{array}{l}\text { Споживання } \\
\text { (Consumption) }\end{array}$} & $\begin{array}{l}\text { Обмежене спожи- } \\
\text { вання (Constrained } \\
\text { consumption) }\end{array}$ & $\begin{array}{l}\text { Частка домогосподарств із часткою загальних витрат } \\
\text { у сімейному бюджеті понад 75\% (у процесі розробки) } \\
\text { (Basic expenses to total household budget ratio higher than } \\
75 \% \text { (to be developed)) }\end{array}$ \\
\hline & \multirow{2}{*}{$\begin{array}{l}\text { Неринкове споживан- } \\
\text { ня та надання дер- } \\
\text { жавних послуг (Non- } \\
\text { market consumption } \\
\text { and government } \\
\text { provided services) }\end{array}$} & $\begin{array}{l}\text { Споживання державних послуг (у процесі розробки) } \\
\text { (Consumption of government services (to be developed)) }\end{array}$ \\
\hline & & $\begin{array}{l}\text { Неринкові послуги (у процесі розробки) (Non-market } \\
\text { services (to be developed)) }\end{array}$ \\
\hline \multirow{4}{*}{$\begin{array}{l}\text { Матеріальні } \\
\text { умови (Material } \\
\text { conditions) }\end{array}$} & \multirow{2}{*}{$\begin{array}{l}\text { Депривація за до- } \\
\text { ходами (Material } \\
\text { deprivation) }\end{array}$} & $\begin{array}{l}\text { Чисельність матеріально депривованих людей (Severely } \\
\text { materially deprived people) }\end{array}$ \\
\hline & & $\begin{array}{l}\text { Неможливість звести кінці з кінцями (Inability to make } \\
\text { ends meet) }\end{array}$ \\
\hline & \multirow[t]{2}{*}{$\begin{array}{l}\text { Житлові умови } \\
\text { (Housing conditions) }\end{array}$} & $\begin{array}{l}\text { Частка від загального населення, що проживає в } \\
\text { житловому приміщенні з дахом, який протікає, сирими } \\
\text { стінами, підлогою чи фундаментом, гнилими віконними } \\
\text { рамами чи полом (Share of total population living in } \\
\text { a dwelling with a leaking roof, damp walls, floors or } \\
\text { foundation, or rot in window frames of floor) }\end{array}$ \\
\hline & & $\begin{array}{l}\text { Задоволеність умовами проживання (на стадії розроб- } \\
\text { ки в } 2013 \text { SILC) (Satisfaction with accommodation (under } \\
\text { development in SILC 2013)) }\end{array}$ \\
\hline
\end{tabular}

Продуктивна чи основна діяльність (Productive or main activity)

\section{Зайнятість} (кількісний вимip) (Quantity of employment)
Безробіття

(Unemployment)
Рівень безробіття за статтю (Unemployment rate by sex)

Рівень довгострокового безробіття за статтю (Long-term unemployment rate by sex) 
Неповна зайнятість (кількісний вимір) (Underemployment, quantity)

Неповна зайнятість (якісний вимір) (Underemployment, quality) городи від зайнятості (Income and benefits from employment)

Здоров'я та безпека на робочому місці (Health and safety at work)

Якість зайнятості (Quality of employment)
Доходи та інші вина-

Люди, які живуть в сім'ях 3 низькою інтенсивністю праці: за віком і статтю, за доходами (квінтилі) та за типом домогосподарства (Реople living in households with very low work intensity: 1) by age and sex and 2) by income quintile and household type)

Відсоток вимушеної неповної зайнятості як відсоток загальної неповної зайнятості за статтю та віком (Involuntary part-time employment as percentage of the total part-time employment, by sex and age (\%))

(у процесі розробки)

Частка низькооплачуваних працівників у \% до усіх працівників (за винятком учнів), за віком, статтю, рівнем освіти (Low wage earners as a proportion of all employees (excluding apprentices) by age and sex and by educational attainment)

Нещасні випадки на робочому місці, проблеми зі здоров'ям та небезпечний вплив (Work related accidents, health problems and hazardous exposure):

$\checkmark$ особи, які повідомляли про нещасні випадки на виробництві протягом останніх 12 місяців (за статтю, віком та освітою) (Persons reporting an accident at work in the past 12 months by sex, age and education);

$\checkmark$ особи, які повідомляли про одну або кілька пов'язаних з роботою проблем зі здоров'ям за останні 12 місяців (за статтю, віком та освітою) (Persons reporting one or more work-related health problems in the past 12 months, by sex, age and education);

$\checkmark$ особи, які повідомляли про вплив факторів, що можуть негативно вплинути на їх фізичний стан та добробут (за статтю, віком та освітою) (Persons reporting exposure to factors that can adversely affect physical well-being, by sex, age and education);

$\checkmark$ особи, які повідомляли про вплив факторів, що можуть негативно позначитися на їх психічному стані (за статтю, віком та освітою) (Persons reporting exposure to factors that can adversely affect mental well-being, by sex, age and education)

Нещасні випадки на виробництві: стандартизований показник рівня травматизації (Accidents at work: standardised incidence rate)

Середня кількість відпрацьованих годин на тиждень на основній роботі за видами економічної діяльності (Average number of usual weekly hours of work in main job by economic activity (NACE Rev. 2))

Баланс роботи та відпочинку (Work/life balance)
Особи, які працюють більше 49 годин (у процесі розробки) (People working more than the ILO/OECD treshold of 49 hours (to be developed))

Зайнятість у незручний час (заміни - вихідні дні - вечірній та нічний час) (Population in employment working during unsocial hours: Shifts - Saturdays - Sundays Evenings - Nights) 
Тимчасова робота (Temporary work)

Оцінка якості зайнятості (Assessment of quality of employment)
Інша основна
діяльність (Other
main activity)
Задоволеність часом, витраченим на поїздку до роботи (у стадії розробки в 2013 SILC) (Satisfaction with commuting time (under development in SILC 2013))

Тимчасові контракти ( у процесі розробки ) (Temporary contracts (To be developed))

Задоволеність місцем роботи (на стадії розробки в 2013 SILC) (Job satisfaction (under development in SILC 2013))

Задоволеність поточною роботою (на стадії розробки в SILC 2013 ) (Satisfaction with current work )

Можливість впливати на зміст і порядок завдань (на стадії розробки в LFS 2015) (Possibility to influence content and order of tasks)

Гарні стосунки з колегами (на стадії розробки в LFS 2015 ) (Good relationship with colleagues)

Гарні стосунки з безпосереднім керівником (на стадії розробки в LFS 2015) (Good relationship with direct supervisor)

(у процесі розробки)

\section{Здоров'я (Health)}

Очікувана тривалість життя (Life expectancy)

Захворюваність і стан здоров'я (Morbidity \& health status)

\section{Здорова та} нездорова поведінка (Drivers: healthy and unhealthy behaviours)
Очікувана тривалість життя при народженні (Number of remaining years expected to live)

Тривалість (роки) здорового життя (Healthy Life Years)

Самооцінка здоров'я (за статтю, віком, рівнем освіти, квінтилями за доходами) (Self-perceived health: by sex, age and educational level, income quintile)

Люди, що мають застарілу хворобу або проблеми зі здоров'ям (за статтю, віком, рівнем освіти, квінтілями за доходами) (Реople having a long-standing illness or health problem: by sex, age and educational level, income quintile)

Самооцінка обмежень в діяльності через проблеми зі здоров'ям (за статтю, віком, рівнем освіти, квінтилями за доходами) (Self-reported limitation in activities because of health problems: by sex, age and educational level, income quintile)

Самооцінка психічного здоров'я (у процесі розробки) (Self-reported mental health )

Психологічний дистрес протягом останніх 4 тижнів (Psychological distress during the past 4 weeks)

Індекс маси тіла (за статтю, віком, рівнем освіти, квінтілями за доходами) (Body Mass Index: by sex, age and educational level, income quintile)

Регулярні курці (щодня палять цигарки) за статтю, віком, рівнем освіти, квінтилями за доходами (Regular smokers:

$\checkmark$ Daily smokers of cigarettes: by sex, age and educational level, income quintile)

Небезпечне споживання алкоголю (у процесі розробки) (Hazardous alcohol consumption)

Практика фізичної активності (на стадії розробки в EHIS 2014) (Practice of physical activity) 


\section{Доступ до \\ закладів \\ охорони \\ здоров'я (Access \\ to healthcare)}

Самооцінка незадоволеності потреб у медичному обстеженні (за бар'єрами, статтю, віком, рівнем освіти, квінтилями за доходами) (Self-reported unmet needs for medical examination:

$\checkmark$ for reasons of barriers of access, by sex, age and educational level, income quintile)

\section{Освіта (Education)}

\begin{tabular}{|c|c|c|}
\hline \multirow{4}{*}{$\begin{array}{l}\text { Компетенції } \\
\text { та навички } \\
\text { (Competences } \\
\text { and skills) }\end{array}$} & \multirow{3}{*}{$\begin{array}{l}\text { Рівень осві- } \\
\text { ти (Educational } \\
\text { attainment } \\
\text { Самооцінка навичок } \\
\text { (Self-reported skills) }\end{array}$} & $\begin{array}{l}\text { Рівень освіти (початкова, середня, вища) (Education } \\
\text { attainment: Lower primary, Upper secondary, Tertiary) }\end{array}$ \\
\hline & & $\begin{array}{l}\text { Особи, які припинили навчання (за статтю) (Early leavers } \\
\text { from education and training by sex) }\end{array}$ \\
\hline & & (у процесі розробки) \\
\hline & $\begin{array}{l}\text { Оцінені навички } \\
\text { (Assessed skills) }\end{array}$ & $\begin{array}{l}\text { Програма міжнародної оцінки компетенцій дорослих } \\
\text { (PIAAC) (Programme for the International Assesssment of } \\
\text { Adult Competencies ) }\end{array}$ \\
\hline $\begin{array}{l}\text { Навчання про- } \\
\text { тягом усього } \\
\text { життя (Life-long } \\
\text { learning) }\end{array}$ & & $\begin{array}{l}\text { Люди, які навчались або брали участь в професійній під- } \\
\text { готовці протягом чотирьох попередніх тижнів (Реople } \\
\text { that participated in education or training in the four } \\
\text { preceding weeks) }\end{array}$ \\
\hline $\begin{array}{l}\text { Можливості } \\
\text { для освіти } \\
\text { (Opportunities } \\
\text { for education) }\end{array}$ & & (у процесі розробки) \\
\hline
\end{tabular}

Дозвілля (відпочинок) та соціальні комунікації (взаємодія) (Leisure and social interactions)

Дозвілля (відпочинок) (Leisure)

Соціальні комунікації (взаємодія)
Дозвілля (кількісна оцінка): наявність та використання часу, в тому числі для догляду за собою; задоволеність часом, використаним на те, що полюбляють робити (Quantity of leisure: availability and time use, including personal care; satisfaction with time to do the things that people like)

Якість відпочинку (Quality of leisure)

Доступ до дозвілля (Access to leisure)

Спілкування з людьми (у тому числі почуття самотності) (Activities with people (including feelings of loneliness))
Задоволеність використанням часу (на стадії розробки в 2013 SILC) (Satisfaction with time use)

(у процесі розробки)

Самооцінка доступу до діяльності, в якій зацікавлені люди (у процесі розробки) (Self-reported access to activities that people are interested in)

Доступ до кіно, театру чи культурного центру (у процесі розробки) (Access to cinema, theatre or cultural centre)

Частота контактів або зустрічей з друзями, родичами або колегами по роботі (у процесі розробки) (Frequency of contacting or meeting socially with friends, relatives or work colleagues)

Задоволення від особистого спілкування (на стадії розробки в 2013 SILC) (Satisfaction with personal relationships) 
Діяльність для людей (Activities for people)

Взаємовідносини підтримки (Supportive relationships)

Соціальна згуртованість (міжособистісна довіра, гостре сприйняття напруженості, нерівності) (Social cohesion (interpersonal trust, perceived tensions, inequalities)
Участь у добровільній та благодійній діяльності поза оплачуваною роботою (у процесі розробки) (Involvement in voluntary and charitable activities out of paid work)

Частка населення, яке вказує, що $є$ хтось, хто може йому допомогти у разі необхідності (у процесі розробки) (Proportion of people indicating they have someone to rely upon for help)

Можливість отримати допомогу (на стадії розробки 2013 SILC) (Ability to get help)

Можливість обговорити особисті питання (на стадії розробки 2013 SILC) (Ability to discuss on personal matters )

Довіра до інших (на стадії розробки 2013 SILC) (Trust in others)
Економічна

безпека i

вразливість

(Economic

security and

vulnerability)

Фізична і

особиста

безпека (Physical and personal security)

Економічна та фізична безпека (Economic and physical safety)

Багатство (активи) (Wealth (assets)

Борг (Debt)

Нестабільність доходів (у тому числі роботи) (Income insecurity (including job)

Сприйняття фізичної безпеки (Perception of physical safety)
Населення, яке не витримає несподіваних фінансових витрат (Population unable to face unexpected financial expenses)

Населення, яке має заборгованість (Population in arrears)

Ймовірність втрати роботи (у процесі розробки) (Likelihood of loosing the job)

Стандартизований за віком рівень вбивств / 100000 осіб (Age-standardized homicide rate / 100000 people)

Злочинність, насильство або вандалізм (Crime, violence or vandalism in the area)

Населення, яке почувається безпечно у темний період доби, йдучи без супроводу в районі (на стадії розробки 2013 SILC) (Population feeling safe when walking alone in their area after dark )

Природа та середовище існування (Natural and living environment)

\section{Забруднення}

(у т. ч. шум)

Pollution

(including noise)

\section{Доступ до зе-} лених і рекреаційних зон (Access to green and recreational spaces)
Забруднення, бруд або інші екологічні проблеми (Pollution, grime or other environmental problems)

Шум від сусідів або з вулиці (Noise from neighbours or from the street)

Сміття на вулиці (у процесі розробки) (Outdoor particulate matter)

Задоволеність зеленими і рекреаційними зонами (на стадії розробки 2013 SILC) (Satisfaction with recreational and green areas) 


\begin{tabular}{|c|c|c|}
\hline $\begin{array}{l}\text { Ландшафт і } \\
\text { антропогенне } \\
\text { середовище } \\
\text { (Landscape and } \\
\text { built environ- } \\
\text { ment) }\end{array}$ & & $\begin{array}{l}\text { Задоволеність середовищем проживання (на стадії } \\
\text { розробки } 2013 \text { SILC) (Satisfaction with living environment) }\end{array}$ \\
\hline \multicolumn{3}{|c|}{ Державне управління (влада) та основні права (Governance and basic rights) } \\
\hline \multirow{2}{*}{$\begin{array}{l}\text { Інституції } \\
\text { (установи) та } \\
\text { громадські } \\
\text { послуги } \\
\text { (Institutions and } \\
\text { public services) }\end{array}$} & $\begin{array}{l}\text { Довіра та/або задо- } \\
\text { волення діяльністю } \\
\text { установ (Trust and/ } \\
\text { or satisfaction in } \\
\text { institutions) }\end{array}$ & $\begin{array}{l}\text { Довіра до інституцій (установ) (на стадії розробки } 2013 \\
\text { SILC) (Trust in institutions) }\end{array}$ \\
\hline & $\begin{array}{l}\text { Довіра і / або задо- } \\
\text { волення у сфері гро- } \\
\text { мадських послуг (Trust } \\
\text { and/or satisfaction in } \\
\text { public services) }\end{array}$ & $\begin{array}{l}\text { Задоволеність громадськими послугами (у процесі роз- } \\
\text { робки) (Satisfaction with public services) }\end{array}$ \\
\hline \multirow{2}{*}{$\begin{array}{l}\text { Дискримінація } \\
\text { та рівні } \\
\text { можливості } \\
\text { (Discrimination } \\
\text { and equal } \\
\text { opportunities) }\end{array}$} & & $\begin{array}{l}\text { Стикаються з дискримінацією (в процесі розробки) } \\
\text { (Experienced discrimination) }\end{array}$ \\
\hline & & $\begin{array}{l}\text { Гендерний розрив в оплаті праці у нескоригованій фор- } \\
\text { мi, \% (Gender pay gap in unadjusted form in \%) }\end{array}$ \\
\hline $\begin{array}{l}\text { Активна } \\
\text { громадянська } \\
\text { позиція (Active } \\
\text { citizenship) }\end{array}$ & & $\begin{array}{l}\text { Право голосу та підзвітність (у процесі розробки) (Voice } \\
\text { and accountability) }\end{array}$ \\
\hline \multicolumn{3}{|c|}{ Загальне сприйняття життя (Overall experience of life) } \\
\hline $\begin{array}{l}\text { Задоволеність } \\
\text { життям (Life } \\
\text { satisfaction) }\end{array}$ & & $\begin{array}{l}\text { Загальна задоволеність життям (на стадії розробки в SILC } \\
\text { 2013) (Overall life satisfaction ) }\end{array}$ \\
\hline \multirow{2}{*}{ Впливи (Affects) } & & $\begin{array}{l}\text { Негативні впливи (на стадії розробки в SILC 2013) } \\
\text { (Negative affects) }\end{array}$ \\
\hline & & $\begin{array}{l}\text { Позитивні впливи (на стадії розробки в SILC 2013) } \\
\text { (Positive affects) }\end{array}$ \\
\hline $\begin{array}{l}\text { Сенс і мета } \\
\text { (Meaning and } \\
\text { purpose) }\end{array}$ & & $\begin{array}{l}\text { Оцінка того, чи життя } \epsilon \text { гідним (на стадії розробки в SILC } \\
\text { 2013) (Assessing whether life is worthwile) }\end{array}$ \\
\hline
\end{tabular}

Інформація щодо даних 8+1 напрямів надходить із декількох джерел у рамках Європейської статистичної системи, зокрема з SILC (статистики доходів та умов життя), LFS (обстеження робочої сили), EHIS (Європейське дослідження стану здоров'я населення), а також адміністративних ресурсів. Також частина індикаторів отримується з джерел, які не є частиною загальноєвропейської статистичної системи. У першу чергу, че стосується даних Європейського обстеження якості життя (EQLS). У планах дослідницької групи - введення спеціальних модулів до статистики доходів та умов життя населення, які детальніше розкриватимуть деякі аспекти якості життя. Також одним із завдань є розробка комплексних показників за кожним із 8+1 напрямів, що помітно спростило баналіз та оцінювання якості жuтmя [ Quality of life indicators/Dackground// http://epp.eurostat.ec.europa.eu/portal/page/portal/quality_life/background]. 
ДОДАТОК $\mathbf{D}$ ПОКАЗНИКИ ОЦІНЮВАННЯ ЯКОСТІ ЖИТТЯ ЗА МЕТОДОЛОГІЕЮ ЖУРНАЛА INTERNATIONAL LIVING

Таблиця В.1 - Напрями та індикатори оцінювання якості життя за методологією International Living

\begin{tabular}{|c|c|}
\hline Напрями оцінювання & Індикатори \\
\hline $\begin{array}{l}\text { Прожитковий мінімум - } \\
\text { вартість життя (Cost of living) }\end{array}$ & $\begin{array}{l}\text { «Вартість» способу життя (за орієнтир береться середній рівень } \\
\text { життя у США) (primary source is the U.S. State Department's Index of } \\
\text { Overseas Living Costs) }\end{array}$ \\
\hline Культура (Culture and Leisure) & $\begin{array}{l}\text { Рівень освіченості (literacy rates), оціночний рейтинг культурних і } \\
\text { культурно-розважальних заходів (subjective rating of the variety of } \\
\text { cultural and recreational offerings) }\end{array}$ \\
\hline Економіка (Economy) & $\begin{array}{l}\text { Процентні ставки (interest rates), ВBП (GDP), темпи зростання ВВП } \\
\text { (GDP growth rate), темпи інфляції (the rate of inflation), ВВП на одну } \\
\text { особу населення (GDP per capita) }\end{array}$ \\
\hline $\begin{array}{l}\text { Навколишнє середовище } \\
\text { (Environment) }\end{array}$ & $\begin{array}{l}\text { Індекс навколишнього середовища (the Environmental Performance } \\
\text { Index (EPI) from Yale University) }\end{array}$ \\
\hline Свобода (Freedom) & Громадянські свободи і політичні права (Freedom House's survey) \\
\hline Здоров'я (Health) & $\begin{array}{l}\text { Кількість лікарняних ліжок на } 1000 \text { осіб (the number of hospital beds } \\
\text { per 1,000 реорle), кількість осіб на одного лікаря (number of people } \\
\text { per doctor), доступ до якісної питної воді (the percentage of the } \\
\text { population with access to safe water), рівень дитячої смертності (the } \\
\text { infant mortality rate), очікувана тривалість життя (life expectancy), ви- } \\
\text { трати на охорону здоров'я у\% до ВВП (public health expenditure as a } \\
\text { percentage of a country's GDP) }\end{array}$ \\
\hline $\begin{array}{l}\text { Інфраструктура } \\
\text { (Infrastructure) }\end{array}$ & $\begin{array}{l}\text { Густота залізничних, судноплавних та автомобільних шляхів (the } \\
\text { length of railways, paved highways, and navigable waterways), кількість } \\
\text { автомобілів, телефонів і мобільних телефонів, Інтернет-провайдерів } \\
\text { на душу населення (the number of airports, motor vehicles, telephones, } \\
\text { Internet and cell phones service providers, per capita) }\end{array}$ \\
\hline $\begin{array}{l}\text { Безпека і ризик (Safety and } \\
\text { Risk) }\end{array}$ & Показники доплат за роботу в небезпечних умовах \\
\hline Клімат (Climate) (вага 10\%) & $\begin{array}{l}\text { Середньорічна кількість опадів (average annual rainfall), середня } \\
\text { температура (average temperature), ймовірність стихійних лих і } \\
\text { природних катаклізмів (risk for natural disasters) }\end{array}$ \\
\hline
\end{tabular}


Таблиця Г.1 - Методологія ЄС European Foundation for the Improvement of Living and Working Conditions: напрями та індикатори оцінювання якості життя

\begin{tabular}{|c|c|}
\hline \multicolumn{2}{|c|}{ Напрям 1 - Здоров'я (Health) } \\
\hline $\begin{array}{l}\text { Очікувана тривалість життя при народженні } \\
\text { (Life expectancy at birth) }\end{array}$ & $\begin{array}{l}\text { Очікувана тривалість життя у віці } 65 \text { років } \\
\text { (Life expectancy at the age of } 65 \text { ) }\end{array}$ \\
\hline $\begin{array}{l}\text { Очікувана тривалість здорового життя } \\
\text { (Healthy life expectancy) }\end{array}$ & $\begin{array}{l}\text { Дитяча смертність } \\
\text { (Infant mortality) }\end{array}$ \\
\hline $\begin{array}{l}\text { Поганий стан здоров'я } \\
\text { (Poor state of health) }\end{array}$ & $\begin{array}{l}\text { Хронічні захворювання } \\
\text { (Chronic Illness) }\end{array}$ \\
\hline $\begin{array}{l}\text { Паління } \\
\text { (Smoking) }\end{array}$ & $\begin{array}{l}\text { Надмірна вага } \\
\text { (Overweight) }\end{array}$ \\
\hline $\begin{array}{l}\text { Знижена маса } \\
\text { (Underweight) }\end{array}$ & $\begin{array}{l}\text { Відстань до лікаря загальної практики } \\
\text { (Distance from a general practitioner) }\end{array}$ \\
\hline $\begin{array}{l}\text { Відстань від лікарні загального профілю } \\
\text { (Distance from a general hospital) }\end{array}$ & $\begin{array}{l}\text { Медичні працівники } \\
\text { (Medical practitioners) }\end{array}$ \\
\hline $\begin{array}{l}\text { Задоволеність національною системою охорони } \\
\text { здоров'я } \\
\text { (Satisfaction with the national health care system) }\end{array}$ & $\begin{array}{l}\text { Якість послуг національної системи охорони } \\
\text { здоров'я } \\
\text { (Quality of national health service) }\end{array}$ \\
\hline $\begin{array}{l}\text { Витрати на охорону здоров'я у відсотках від ВВП } \\
\text { (Health care expenditure as a share of GDP) }\end{array}$ & $\begin{array}{l}\text { Витрати у рамках сектору охорони здоров'я } \\
\text { (Expenses within the health sector) }\end{array}$ \\
\hline \multicolumn{2}{|c|}{ Напрям 2 - Зайнятість (Employment) } \\
\hline $\begin{array}{l}\text { Рівень зайнятості } \\
\text { (Employment rate) }\end{array}$ & $\begin{array}{l}\text { Рівень безробіття } \\
\text { (Unemployment rate) }\end{array}$ \\
\hline $\begin{array}{l}\text { Тривале безробіття } \\
\text { (Long-term unemployment) }\end{array}$ & $\begin{array}{l}\text { Рівень безробіття серед молоді } \\
\text { (Youth unemployment rate) }\end{array}$ \\
\hline $\begin{array}{l}\text { Робота під стресом } \\
\text { (Find work stressful) }\end{array}$ & $\begin{array}{l}\text { Робота під контролем } \\
\text { (Control over work tasks) }\end{array}$ \\
\hline $\begin{array}{l}\text { Робота рутинна } \\
\text { (Work is boring) }\end{array}$ & $\begin{array}{l}\text { Робота в стислі терміни } \\
\text { (Work to tight deadlines) }\end{array}$ \\
\hline $\begin{array}{l}\text { Робота в небезпечних або шкідливих для здоров'я } \\
\text { умовах } \\
\text { (Work in dangerous or unhealthy conditions) }\end{array}$ & $\begin{array}{l}\text { Робота не залишає часу для сім'ï } \\
\text { (Job prevents giving time to the family) }\end{array}$ \\
\hline $\begin{array}{l}\text { Партнери/сім'я, незадоволені роботою } \\
\text { (Partner/family gets fed up with job pressure) }\end{array}$ & $\begin{array}{l}\text { Втома після роботи } \\
\text { (Too tired after work) }\end{array}$ \\
\hline $\begin{array}{l}\text { Задоволення від роботи } \\
\text { (Job satisfaction) }\end{array}$ & $\begin{array}{l}\text { Важливість роботи } \\
\text { (Importance of work) }\end{array}$ \\
\hline $\begin{array}{l}\text { Вірогідність втрати роботи } \\
\text { (Likelihood of losing the job) }\end{array}$ & $\begin{array}{l}\text { Очікувані особисті ситуації на роботі } \\
\text { (Expected personal job situation) }\end{array}$ \\
\hline \multicolumn{2}{|l|}{$\begin{array}{l}\text { Кількість годин роботи на тиждень } \\
\text { (Hours of work per week) }\end{array}$} \\
\hline \multicolumn{2}{|c|}{ Напрям 3 - Депривації за доходами (Income deprivation) } \\
\hline $\begin{array}{l}\text { Нерівність розподілу доходів } \\
\text { (Inequality of income distribution) }\end{array}$ & $\begin{array}{l}\text { Індекс Джині } \\
\text { (Gini index) }\end{array}$ \\
\hline $\begin{array}{l}\text { Індекс депривації (позбавлення) } \\
\text { (Deprivation index) }\end{array}$ & $\begin{array}{l}\text { Труднощі зведення кінців з кінцями } \\
\text { (Difficulties in making ends meet) }\end{array}$ \\
\hline
\end{tabular}


Неспроможність заплановано сплачувати рахунки (Unable to pay scheduled bills)

Задоволеність рівнем життя

(Satisfaction with standard of living)

Очікуваний фінансовий стан домогосподарства (Expected financial situation of household)

Ризик бідності

(At risk of poverty rate)
Неспроможність платити за харчування

(Inability to pay for food)

Незадоволеність фінансовим станом

(Dissatisfaction with financial situation)

Ризик тривалої бідності

(Persistent at risk of poverty rate)

\section{Напрям 4 - Освіта (Education)}

\section{Навички читання}

(Reading skills)

Навички в галузі науки

(Skills in science)

Охоплення вищою освітою

(Higher education enrolment)

Середня освіта (25-64 років)

(At least upper secondary education (25-64 age group))

Державні витрати на освіту

(Public expenditure on education)

Задоволеність освітою

(Satisfaction with education)

\section{Навички в математиці}

(Skills in mathematics)

Середня освіта (20-24 років)

(Secondary school education (20-24 age group))

Участь жінок у вищих навчальних закладах

(Female participation in tertiary education)

Участь у тренінгах або курсах

(Attended a training or education course)

Якість системи освіти

(Quality of education system)

\section{Напрям 5 - Сім'я (Family)}

Рівень розлучень

(Divorce rate)

Сім'ї, що складаються з однієї людини

(Single person households)

Кількість позашлюбних народжень

(Non-marital births)

\section{Задоволеність сімейним життям}

(Satisfaction with family life)

Відчуття виключеності із родини

(Feel left out of family)

Підтримка з боку членів сім'ї

(Support from family members)
Сім'ї з одним із батьків

(Single parent households)

Вік жінки при народженні першої дитини

(Age of woman at first birth)

Догляд за хворими, інвалідами або людьми похилого віку на дому

(Caring for ill, disabled or elderly in the home)

Важливість сім'ї

(Importance of family)

Справедливий розподіл сімейних обов'язків

(More than fair share of family responsibilities)

Загальний коефіцієнт шлюбності

(Crude marriage rate)

Середній вік вступу в перший шлюб

(Mean age at first marriage)

Напрям 6 - Суспільне життя (Social participation)

\section{Контакти з сусідами}

(Contact with neighbours)

Членство в організації

(Membership in an organisation)

Діяльність у релігійній організації

(Activity in a religious organisation)

Діяльність в організації з особистих причин

(Activity in an organisation for personal reasons)

Доступ до Інтернету

(Internet access of households)
Зустрічі з друзями або родичами (Meeting friends or relatives)

Відвідування релігійних служб (Religious service attendance)

Діяльність у політичній чи благодійній організації (Activity in a political or charitable organisation)

Використання Інтернету

(Use of the Internet)

Довіра до представницької демократії

(Trust in democratic representatives) 
Довіра до людей

(Trust in people)

Голосування в останніх виборах

(Voted in last election)
Задоволеність суспільним життям

(Satisfaction with social life)

Напрям 7 - Житло (Housing)

\begin{tabular}{l|l}
\hline $\begin{array}{l}\text { Кількість людей у кімнаті } \\
\text { (Persons per room) }\end{array}$ & $\begin{array}{l}\text { Відсутність додаткової площі } \\
\text { (No place to sit outside) }\end{array}$ \\
\hline $\begin{array}{l}\text { Туалет на дворі } \\
\text { (No indoor flushing toilet) }\end{array}$ & $\begin{array}{l}\text { Проблеми з житлом } \\
\text { (Problems with the accommodation) }\end{array}$ \\
\hline $\begin{array}{l}\text { Oренда житла } \\
\text { (Renting the dwelling) }\end{array}$ & $\begin{array}{l}\text { Пряма власність житла } \\
\text { (Owning the dwelling outright) }\end{array}$ \\
\hline $\begin{array}{l}\text { Власність житла за iпотекою } \\
\text { (Оwning the dwelling with a mortgage) }\end{array}$ & $\begin{array}{l}\text { Середні витрати на житло } \\
\text { (Average housing costs) }\end{array}$ \\
\hline $\begin{array}{l}\text { Ускладнення з оплатою житла } \\
\text { (Ноusing соsts a heavy burden) }\end{array}$ & $\begin{array}{l}\text { Отримання допомоги на житло } \\
\text { (Receiving housing allowance) }\end{array}$ \\
\hline $\begin{array}{l}\text { Задоволеність житлом } \\
\text { (Satisfaction with the home) }\end{array}$ & \\
\hline
\end{tabular}

Напрям 8 - Навколишнє середовище (Environment)

Відстань до банкомата (Distance from a cash dispenser)

Відстань до магазину чи супермаркету (Distance from a shop or supermarket)

Відстань до найближчої початкової школи (Distance to the nearest primary school)

Скарги на якість питної води (Complain about the quality of drinking water)

Скарги на розміщення відходів (Complain about waste disposal)

Скарги на пошкодження краєвиду (Complain about damage to the landscape)

Репутації місця проживання (Area has not got a good reputation)
Відстань до кінотеатру (Distance from a cinema)

Відстань до найближчого дитячого садку (Distance to the nearest nursery)

Забруднення від транспорту або промисловості в районі (Experience pollution from traffic or industry in the local area)

\section{Скарги на шум (Complain about noise)}

Скарги на відсутність зелених насаджень (Complain about the lack of green spaces)

Будинки в поганому стані (Buildings in a bad state of repair)

Задоволеність місцем проживання (Satisfaction with the area you live in)

\section{Напрям 9 - Транспорт (Transport)}

Загальна мобільність (General mobility)

Володіння автомобілем (Car ownership)

Безпека дорожнього руху (зі смертельним результатом) (Road safety (fatalities))

Час, потрібний щоб дістатися до наступної зупинки громадського транспорту (Time to get to the next public transport stop)

Якість громадського транспорту (Quality of public transport)
Щільність залізниці (Railway density)

Безпека дорожнього руху (аваріï) (Road safety (accidents))

Час на поїздки (Commuting time)

Скарги на транспортний трафік (Complains about traffic problems)

Домогосподарства, які не можуть дозволити собі автомобіль (Households which cannot afford a car)

\section{Напрям 10 - Безпека (Safety)}

Грабежі і крадіжки (Robbery and thefts)

Крадіжки у минулому році (Burglaries in the past year) 
Крадіжки в останні п'ять років (Burglaries in the past five years)

Напади і погрози (Assaults and threats)

Обман споживачів (Consumer fraud)

Вандалізм і крадіжки в місцевості (Vandalism and theft in the area)

Небезпека ходити у нічний час (Unsafe to walk around at night)

Довіра до поліції (Trust in the police)

Задоволеність роботою поліції (Satisfaction with the work of the police)
Сексуальні злочини (Sexual offences)

Випадки корупції (Corruption)

Злочинність та вандалізм (Crime and vandalism)

Занепокоєність з приводу крадіжки (Concern about burglary)

Відстань до найближчого поліцейського відділку (Distance to the nearest police station) Довіра до судової системи (Trust in the judicial system)

\section{Напрям 11 - Відпочинок (Leisure)}

Час, витрачений на сімейні заходи (Time spent for family activities)

Час, витрачений на соціальні заходи (Time spent on social activities)

Час, витрачений на відпочинок (Time spent relaxing)

Час, витрачений на перегляд ТВ програм (Watching TV)

Використання молоддю мультимедіа (Young people's use of multimedia)

Участь молоді у творчій діяльності (Young people's involvement in artistic activities)

Звичка молодих людей читати (Young people's reading habits)

Важливість дозвілля (Importance of leisure)

Напрям 12 - Задоволеність життям (Life satisfaction)

Індекс корупції (Corruption Perceptions Index (CPI)

Якість соціальних послуг (Quality of social services)

Напруженість у відносинах між молодими і літніми людьми (Tensions between young and old people)

Напруженість у відносинах між різними етнічними групами (Tensions between different ethnic groups)

Намагання людей бути корисними (People try to be helpful)

Задоволеність життям (Life satisfaction)

Щастя (Happiness)
Час, витрачений на спорт (Time spent on sports)

Час, витрачений на культурні заходи (Time spent on cultural activities)

Час, витрачений на волонтерську роботу чи політичну діяльність (Time spent on voluntary work or political activities)

Участь молоді у спорті (Young people's involvement in sport)

Участь молоді у заходах на свіжому повітрі (Young people's involvement in outdoor activities)

Участь молоді у субсидіарних заходах (Young people's involvement in support and subsidiary activities)

Задоволеність кількістю вільного часу

(Satisfaction with the amount of leisure time)

Нестача часу на захоплення та інтереси (Тоо

little time for hobbies and interests) 
nasuma

ПОКАЗНИКИ ОЦІНЮВАННЯ ЯКОСТІ ЖИТТЯ ЗА МЕТОДОЛОГІЄЮ ОРГАНІЗАЦІЇ ЕКОНОМІЧНОГО СПІВРОБІТНИЦТВА ТА РОЗВИТКУ (ВЕTTER LIFE INDEX)

Таблиця Д.1 - OECP: Better Life Index

\begin{tabular}{|c|c|}
\hline Аспекти якості життя & Індикатори \\
\hline $\begin{array}{l}\text { Житлові умови } \\
\text { (Housing) }\end{array}$ & $\begin{array}{l}\text { Кількість кімнат на одну особу (Rooms per person) } \\
\text { Житло без базових зручностей (Dwellings without basic facilities) } \\
\text { Співвідношення витрат на житло до чистих наявних доходів } \\
\text { домогосподарства (Housing expenditure) }\end{array}$ \\
\hline Доходи (Income) & $\begin{array}{l}\text { Чисті наявні доходи домогосподарства (Household net adjusted disposable } \\
\text { income) } \\
\text { Фінансовий стан домогосподарств: фінансові активи - заощадження, акції } \\
\text { мінус фінансові зобов'язання - позики (Household net adjusted disposable } \\
\text { income) }\end{array}$ \\
\hline $\begin{array}{l}\text { Праця } \\
\text { (Jobs) }\end{array}$ & $\begin{array}{l}\text { Рівень зайнятості (Employment rate) } \\
\text { Рівень довгострокового безробіття (більше } 1 \text { року) (Long-term } \\
\text { unemployment rate) } \\
\text { Особисті заробітки, на рік на одного працюючого на повну ставку (Personal } \\
\text { earnings) } \\
\text { Гарантії зайнятості - відсоток працівників з контрактами на } 6 \text { і менше } \\
\text { місяців (Job security) }\end{array}$ \\
\hline $\begin{array}{l}\text { Громада } \\
\text { (Community) }\end{array}$ & $\begin{array}{l}\text { Якість мережі підтримки (відсоток людей, які мають родичів і знайомих, } \\
\text { до кого можуть звернутися в разі потреби) (Gallup World Poll) (Quality of } \\
\text { support network) }\end{array}$ \\
\hline $\begin{array}{l}\text { Освіта } \\
\text { (Education) }\end{array}$ & $\begin{array}{l}\text { Рівень освіти - частка осіб серед 25-64-літніх, які мають освіту вище } \\
\text { середньої загальної (Educational attainment) } \\
\text { Навички студентів - результати 15-літніх за порівняльними тестами PISA } \\
\text { (Student skills) } \\
\text { Очікуване число років формальної освіти (Years in education) }\end{array}$ \\
\hline $\begin{array}{l}\text { Навколишнє } \\
\text { середовище } \\
\text { (Environment) }\end{array}$ & $\begin{array}{l}\text { Забруднення повітря (Air pollution) } \\
\text { Якість води - відсоток людей, задоволених якістю місцевої води (Water } \\
\text { quality) }\end{array}$ \\
\hline $\begin{array}{l}\text { Участь у суспільному } \\
\text { житті } \\
\text { (Civic engagement) }\end{array}$ & $\begin{array}{l}\text { Явка на вибори (Voter turnout) } \\
\text { Консультації у процесі законотворчості (Consultation on rule-making) }\end{array}$ \\
\hline $\begin{array}{l}\text { Здоров'я } \\
\text { (Health) }\end{array}$ & $\begin{array}{l}\text { Очікувана тривалість життя (Life expectancy) } \\
\text { Самооцінка здоров'я - відсоток людей, які оцінили своє здоров'я як } \\
\text { «хороше» або «дуже хороше» (Self-reported health) }\end{array}$ \\
\hline $\begin{array}{l}\text { Задоволеність життям } \\
\text { (Life Satisfaction) }\end{array}$ & Самооцінка задоволеності життям за шкалою від 0 до 10 (Life satisfaction) \\
\hline $\begin{array}{l}\text { Безпека } \\
\text { (Safety) }\end{array}$ & $\begin{array}{l}\text { Рівень небезпеки - частка осіб, які піддалися нападам або пограбуванням } \\
\text { за останні } 12 \text { місяців (Assault rate) } \\
\text { Рівень вбивств - кількість вбивств на } 100 \text { тис. населення (Homicide rate) }\end{array}$ \\
\hline $\begin{array}{l}\text { Баланс праці та } \\
\text { відпочинку } \\
\text { (Work-Life Balance) }\end{array}$ & $\begin{array}{l}\text { Частка працівників, які працюють понаднормово (більше } 50 \text { годин на } \\
\text { тиждень) (Employees working very long hours) } \\
\text { Час, присвячений відпочинку і догляду за собою (у тому числі на сон та } \\
\text { харчування) (Time devoted to leisure and personal care) }\end{array}$ \\
\hline
\end{tabular}


